\title{
Influence of cultivar or nutrients application on growth, flower production and bulb yield of the common hyacinth
}

\author{
I. K. Addai \\ Author's address: Flat 38F, Park Village, Sussex University, Falmer, Brighton, UK, BN1 9RD \\ (Current address); or The Agronomy Department, UDS, P. O. Box 1350, Tamale, Ghana \\ (Permanent address). E-mail: isaackwaheneaddai@yahoo.com; Tel: 00447919610749
}

\begin{abstract}
Research was conducted at the Biology and Environmental Science Department of the University of Sussex, UK to investigate the influence of cultivar or nutrients application on the growth and development of the common hyacinth. Results indicated that cultivars such as Sky Jackets and Purple Voice should be considered by growers in their selection of planting materials for propagation for high bulb or bulblets production, whilst Fondant and Blue Jacket should be planted for flower production, cut flowers or for perfumery uses as they have the genetic potential of producing high flower biomass. But for indoor decorations, Pink Pearl or Jon Bos may be grown by growers. Though the application of $\left(\mathrm{NH}_{4}\right)_{2} \mathrm{SO}_{4}$ or $\mathrm{Na}_{2} \mathrm{HPO}_{4}$ enhanced vegetative growth of hyacinth, plants fertilised with $60-90 \mathrm{mM}\left(\mathrm{NH}_{4}\right)_{2} \mathrm{SO}_{4}$ recorded higher vegetative growth, delayed in senescence, and produced higher bulb and bulblets yield than the control and those fertilised with $\mathrm{Na}_{2} \mathrm{HPO}_{4}$. In general, the application of $\mathrm{Na}_{2} \mathrm{HPO}_{4}$ at the rate of $60-90 \mathrm{mM}$ to the plants resulted in good flower quality.
\end{abstract}

Keywords: The common hyacinth, cultivar, vegetative growth, flower quality, bulb and bulblets yield, nutrients application.

\section{INTRODUCTION}

Flower bulbs are grown mainly for the production of cut flowers, as potted plants or as landscaping plants. Some of the major production problems in bulb production, according to Doyle et al. (1995) are extended flooding during harvest times, excessive heat and drought especially during hot summer seasons, very cold winter seasons, and the occurrence of diseases and pests. But in general, these production problems can be controlled when growers practise good management or agronomic practices. For instance, the use of pumps to remove water from fields which are flooded can minimize flooding and the associated rot problems. Similarly, the problem of drought and excessive heat during flower bulb production may be reduced by mulching because this practice checks water loss by evaporation and conserves soil moisture. Irrigation may also be carried out to make water available for plant uptake. Many growers have also carried out soils testing and fumigation to control nematode infestation and other related soil-borne diseases. In addition, the use of herbicides and pesticides will check weeds and pests, respectively, whilst adopting husbandry practices such as the timely use of fungicides, crop rotation, and the use of good cultivars (Hanks, 2002) have proved effective in improving the yield of flower bulbs. In general, plants are grown in environments whose indices vary in a number of parameters: disease and pest infestations, soil moisture availability, soil nutrient levels, soil and air temperature, light duration, light intensity and relative humidity. But the growth and developmental processes of plants interact with the environmental factors to influence the level of productivity or quality of that plant. One should not, therefore, underestimate or belittle the environment in which the plant is growing. Manipulating the immediate environment of plants by embarking on sound agronomic practices will not only allow plants to grow optimally, but will enhance the production of good quality products and yield.

The importance of supplying nutrients to correct soil infertility and to increase productivity in plants cannot be overemphasized. Nutrients such as nitrogen, phosphorus and potassium play a major role in the growth and development of plants (Scott, 2008). These essential nutrient elements improve the chemical and biological properties of the soil, and therefore enhance higher yields of plants. Research by a number of authors: Silberbush et al. (2003), Kim et al. (1998) and Engelbrecht (2004) have all emphasized the need to supply nutrients to the soil during the growth of plants to increase their quality or 
productivity. The common hyacinth, Hyacinthus orientalis is a spring-flowering bulb and an ornamental geophyte belonging to the family Hyacinthaceae and the genus Hyacinthus. It is a native of the West and Central Asia. The diploid forms of the plant have 16 chromosomes of 5 different types, but there are also triploids $(3 n=24)$ and a large number of heteroploid (Rees, 1972). Flowers are hermaphroditic, and have a strong sweet fragrance that can fill the air for a considerable distance (Gender, 1994). The flowers are generally pollinated by bees (Davis, 1990). Hyacinth is an ornamental geophyte and is grown for its aesthetic uses, but the flower is also used in the perfumery industries for the production and extraction of essential oil. Usher (1974) reported that an amount of $6,000 \mathrm{~kg}$ of the flowers produces $1 \mathrm{~kg}$ of the oil. The plant also produces blue dye. Over the years, many hyacinth cultivars have been developed by breeders, and these genotypes may vary from each other in a number of traits. For instance, different cultivars of plants may have different growth rates, and variations in growth of a plant may not only influence its photosynthetic ability but also their yield at harvest. According to Troughton (1970), differences in growth and development of plant genotypes may be due to among other factors, their variations in genetic makeup, and/or genotype $x$ environment interaction. Variation in characteristics of hyacinth cultivars will allow their evaluation, to determine their suitability for different markets or enhance selection for desirable traits of these plants. In fact, it has been established that (Heins et al., 2000) consumers of flower plants often require detailed specifications from growers involved in the horticultural flower bulb production for products they buy both in times of delivery, and in terms of quality factors such as height, flower number and other features of the plant. However, research on the specific details on the effects of cultivar or nutrients application on the growth and productivity of hyacinth is lacking, and this needs to be addressed. My earlier work on carbohydrate metabolism on hyacinth (Addai, 2010) indicated that reserved carbohydrates, basically starch of the bulb scales decreased to about $50 \%$ of the initial value, at about one month after planting. This decrease mainly coincided with the time of sprouting of the bulb. But in ornamental geophytes, the initial growth and development of the plant depends on the reserves stored in the bulbs (Wassink, 1965; Theron and Jacobs, 1996). Therefore, a reduction in the stored reserves, following sprouting and emergence would have major consequences on the subsequent growth and development of the plant. The present studies were therefore conducted with a view to determining the influence of cultivar, or some nutrients application on the growth and yield of hyacinth.

\section{MATERIALS AND METHODS}

Design and set up of experiments: In this study, hyacinth bulbs of average fresh weight of $55 \mathrm{~g}$ at the time of planting were used. The bulbs were planted in plastic pots; the capacity of each was $0.01 \mathrm{~m}^{3}$. Prior to planting, pots were filled with compost and perlite mixture in a ratio of $2: 1$ by volume. The units were arranged randomly on greenhouse benches using randomised complete block design. Basically, two experiments were conducted. In the first experiment (experiment 1), the following cultivars of hyacinth: Purple Voice, Jon Bos, Sky Jackets, Pink Pearl, Fondant, Blue Jacket, Amethyst and Splendid Cornelia were evaluated to determine their suitability for use as cut flowers, landscaping plants, potted plants or for bulb production. In another experiment (experiment 2), ammonium sulphate i.e. $\left(\mathrm{NH}_{4}\right)_{2} \mathrm{SO}_{4}$, or dibasic sodium hydrogen phosphate i.e. $\mathrm{Na}_{2} \mathrm{HPO}_{4}$ was applied on weekly basis, each at three levels (i.e. 30,60 and $90 \mathrm{mM}$ ) from 8 to 20 weeks after planting to investigate the effects of these nutrients on growth and yield of hyacinth using the cultivar Sky Jacket as the test plant. Plants that received no nutrients application were considered as control. The studies were conducted at the Plant Stress Unit of the Biology and Environmental Science Department of the University of Sussex, Falmer, UK. All plants were purchased from the Spalding Plant and Bulb Company, UK.

\section{Methods of data collection}

Leaf growth: Leaf length was measured as the length of the leaf from the base to the leaf tip, whilst leaf width was measured as the distance at the middle section of the leaf where it is broadest. Total leaf length and width were recorded as the sum of all the individual leaf lengths and widths for one particular plant. Total leaf area was deduced from leaf length and width as described below. The method employed in the determination of leaf area was modified from the procedure used by Darkwa (2008). The leaves of 40 plants of hyacinth grown in the greenhouse were obtained through a destructive sampling. The product of the length and broadest part of the leaf (width) was recorded as measured leaf area (MLA) for all these leaves. Then, outlines or shapes of these leaves were sketched on A-4 papers, and cut out with a pair of scissors. These pieces of papers were weighed separately using an 
electronic weighing balance and the weight of each piece of paper was recorded as leaf paper weight (LPW). The lengths and widths of three of such A-4 papers were multiplied in order to get areas of these A-4 papers, and the average area of the three A-4 papers was divided by the average weight to get a constant value. This constant value was multiplied by the weight of each piece of paper (LPW) obtained by cutting out the leaf outlines and the value recorded as the leaf true area (LTA). A graph of LTA was plotted against MLA and a line of best fit was made to pass through the points, such that the gradient of this line was taken as the leaf area constant value for this species as shown in Figure 1. Thus for instance, the leaf area constant value for hyacinth was 0.9543 . Therefore the leaf area (LA) for one particular leaf was calculated as MLA $\times 0.9543$, and the total leaf area for the whole plant is the sum of (MLA x 0.9543) of all leaves on one particular plant.

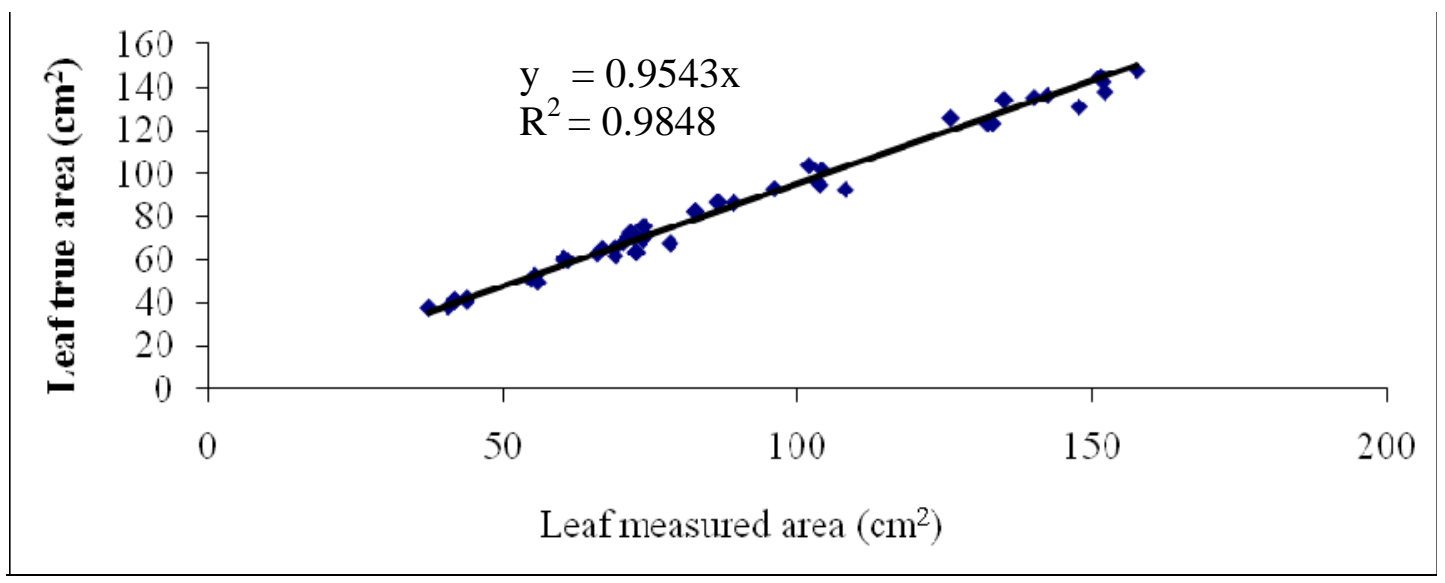

Fig 1: Determination of leaf area constant for the common hyacinth.

Flower quality: Flower quality was measured in terms of inflorescence length or height, inflorescence diameter, inflorescence stalk diameter, and number of florets. The inflorescence height was recorded as the distance from the soil surface level of each plant to the tip of the inflorescence. Inflorescence length was taken as the inflorescence height minus the length of the stalk holding the inflorescence. Inflorescence stalk diameter was measured as the growth in girth of the stalk holding the inflorescence that is, it is a measure of thickness of the inflorescence stalk. Similarly, inflorescence diameter was recorded as a measure of inflorescence thickness before the opening of the florets, and this was measured as the growth in girth of the inflorescence. All these parameters were recorded using a ruler but the number of florets was recorded by counting them after they were fully opened.

Bulb fresh weight: The fresh weights of bulbs were recorded with an electronic weighing balance as the weight of the bulbs prior to planting. At harvest, gain in fresh weight was simply measured as the harvest weight less the initial fresh weight at planting.

Photosynthetic parameters: Leaf chlorophyll concentration was measured with a SPAD chlorophyll meter (Minolta SPAD-502) that gives a relative index of the leaf chlorophyll concentration. The instrument was first calibrated and clipped to three points that is the lower part, the middle portion and towards the tip of the leaf whose chlorophyll content was desired. The first three leaves starting from the outermost leaf of the plant were considered for measurement, and averages were computed for each plant prior to the analysis of this data. Using the infrared gas analyser (Ciras-1 PP Systems), photosynthetic rate and stomatal conductance were determined between the hours of $12: 00$ and $15: 00$ at the prevailing solar radiation. A known area from the leaves used for chlorophyll measurement was clipped with the cuvette of the IRGA, and measurements were made once the leaves had acclimatised to the conditions.

\section{RESULTS}

Cultivar and plant growth and development: The cultivars were basically evaluated to determine their characteristics and suitability in terms of bulb yield, plant height or for flower production. Results indicated that all the cultivars except Jon Bos and Pink Pearl produced relatively high vegetative growth as shown by their leaf width, length and area (Fig $2 a$ and b; Fig 3a). Sky Jacket produced the highest leaf growth whilst Jon Bos recorded the least leaf growth. In general, rate of leaf growth was low from 14 to 22 
weeks after planting but high between 22 and 24 weeks after planting. Chlorophyll content also increased from 14 to 24 weeks after planting and decreased from 24 to 28 weeks after planting. Sky Jacket, followed by Purple Voice gave the highest values in terms of chlorophyll concentration (Fig 3b) whilst Jon Bos and Blue Jackets recorded the least values. With regard to flower quality, Fondant produced the highest inflorescence height, inflorescence length, inflorescence diameter, inflorescence stalk diameter and number of florets, followed by Blue Jacket and Sky Jacket in that order, whilst Pink Pearl and Amethyst recorded the least of these parameters (Fig 4a and b; Fig $5 a$ and b; Fig $6 a)$. The inflorescence of all the cultivars opened at, or before 24 weeks after planting (Fig 7) with the exception of Amethyst (late maturing) whose florets were fully opened at 26 weeks after planting. Trend in weight gain at harvest closely followed that of leaf growth because Sky Jacket, followed by Purple Voice, produced the highest weight gain whilst Jon Bos recorded the lowest gain in weight at harvest (Fig 6b). A similar observation was made in terms of number and weight of offsets produced by these cultivars (Fig 6c).

(a)

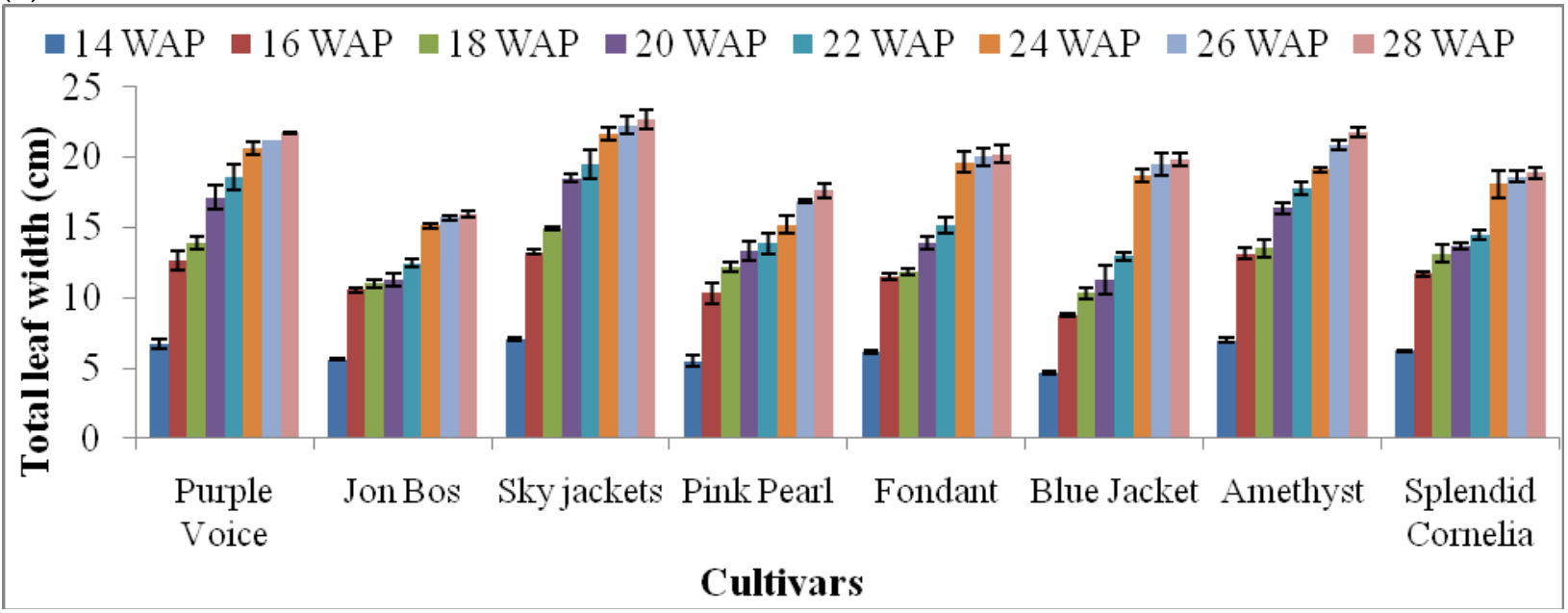

(b)

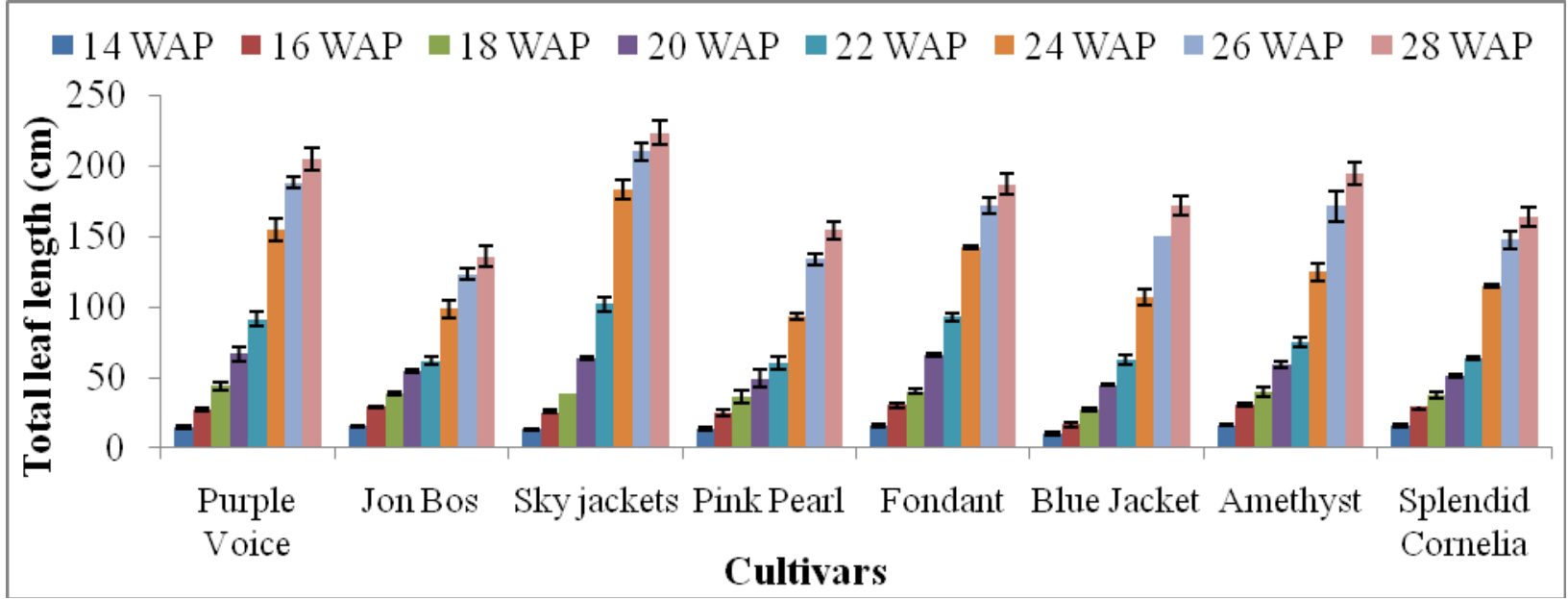

Fig 2: Variations in leaf growth of the eight cultivars: (a) total leaf width, and (b) total leaf length of hyacinth. Bars represent the mean values \pm standard error of five plants. 
(a)

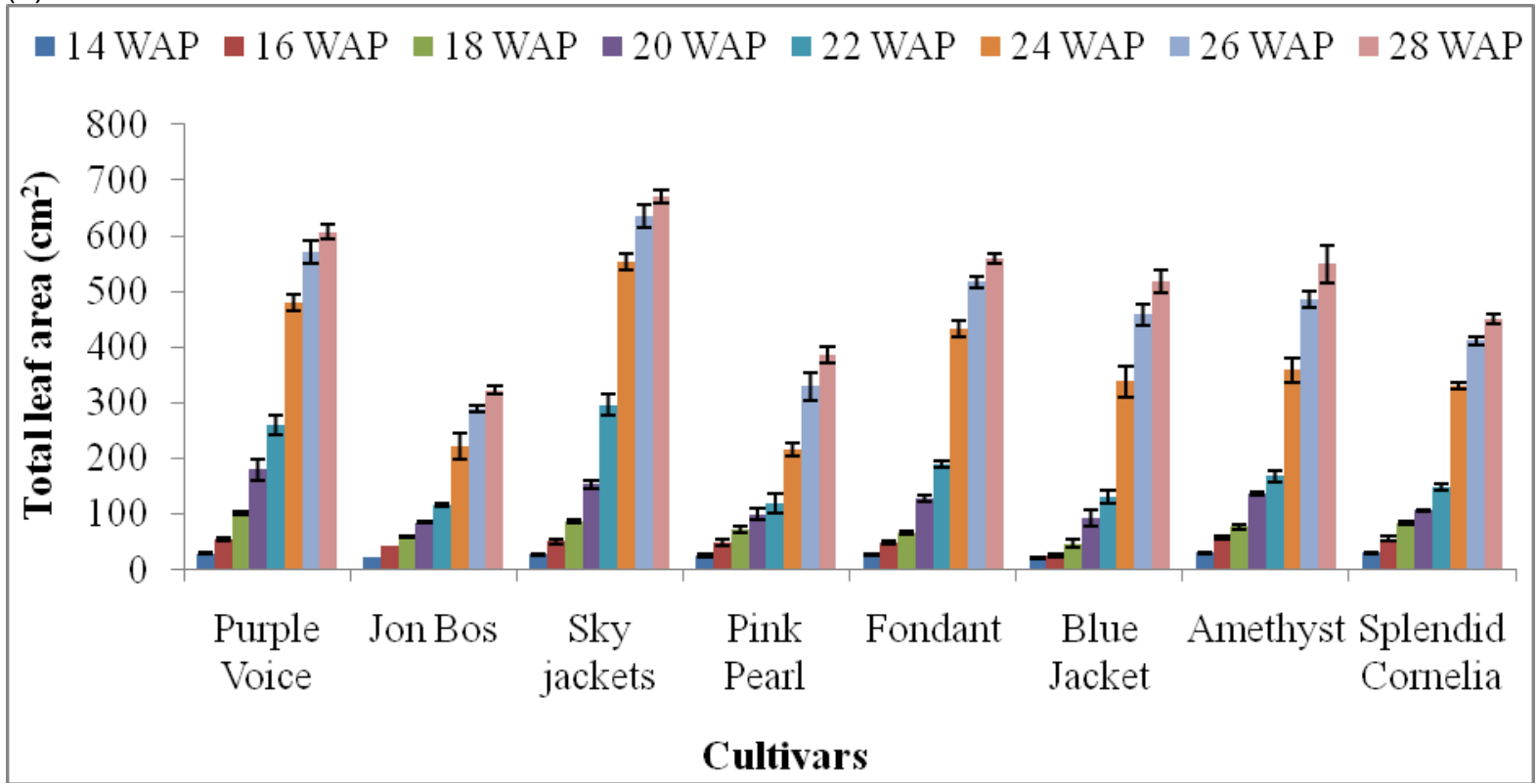

(b)

$\square 14 \mathrm{WAP} \square 16 \mathrm{WAP} \backsim 18 \mathrm{WAP} \approx 20 \mathrm{WAP} \approx 22 \mathrm{WAP} \approx 24 \mathrm{WAP} \approx 26 \mathrm{WAP} \approx 28 \mathrm{WAP}$

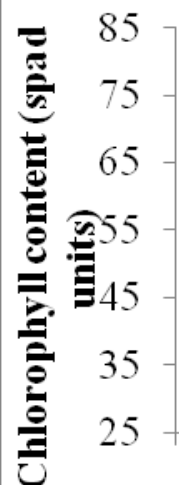

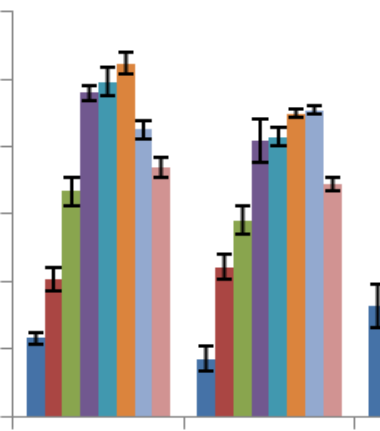

Purple Jon Bos Voice

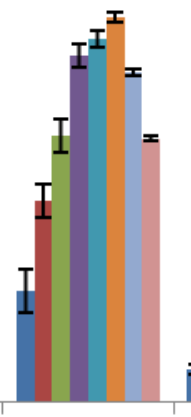

Sky jackets

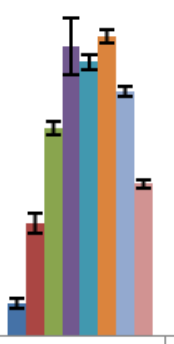

Pink Pearl

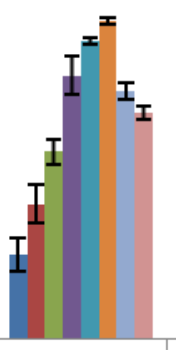

Fondant Cultivars

Fig 3: Influence of cultivar on (a) total leaf area, and (b) chlorophyll content of hyacinth. Bars represent the mean values \pm standard error of five plants. 
Am. J. Sci. Ind. Res., 2011, 2(2): 229-245

(a)

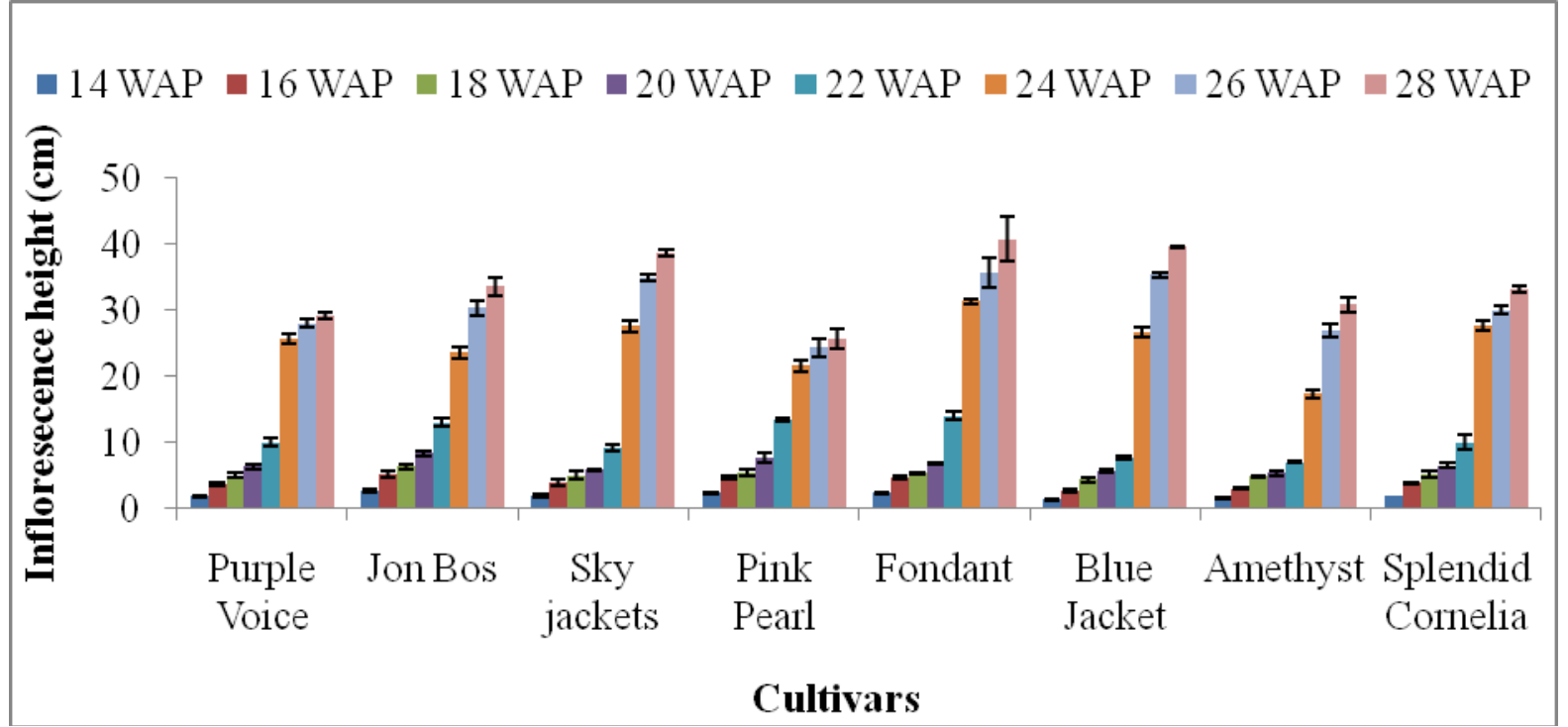

b)

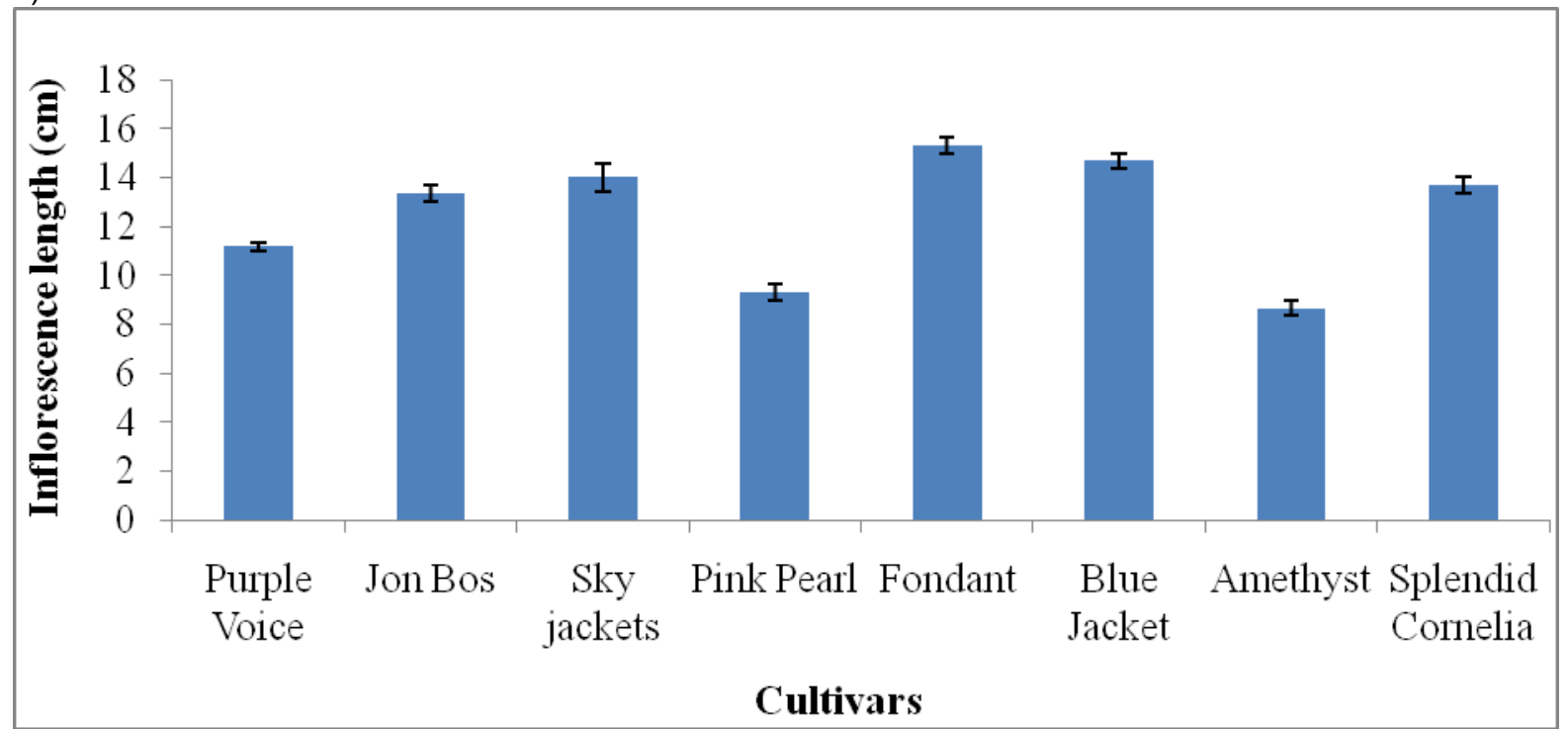

Fig 4: Influence of cultivar on (a) inflorescence height, and (b) inflorescence length of hyacinth. The inflorescence lengths presented are the values measured at 28 weeks after planting. Bars represent the mean values \pm standard error of five plants. 
(a)

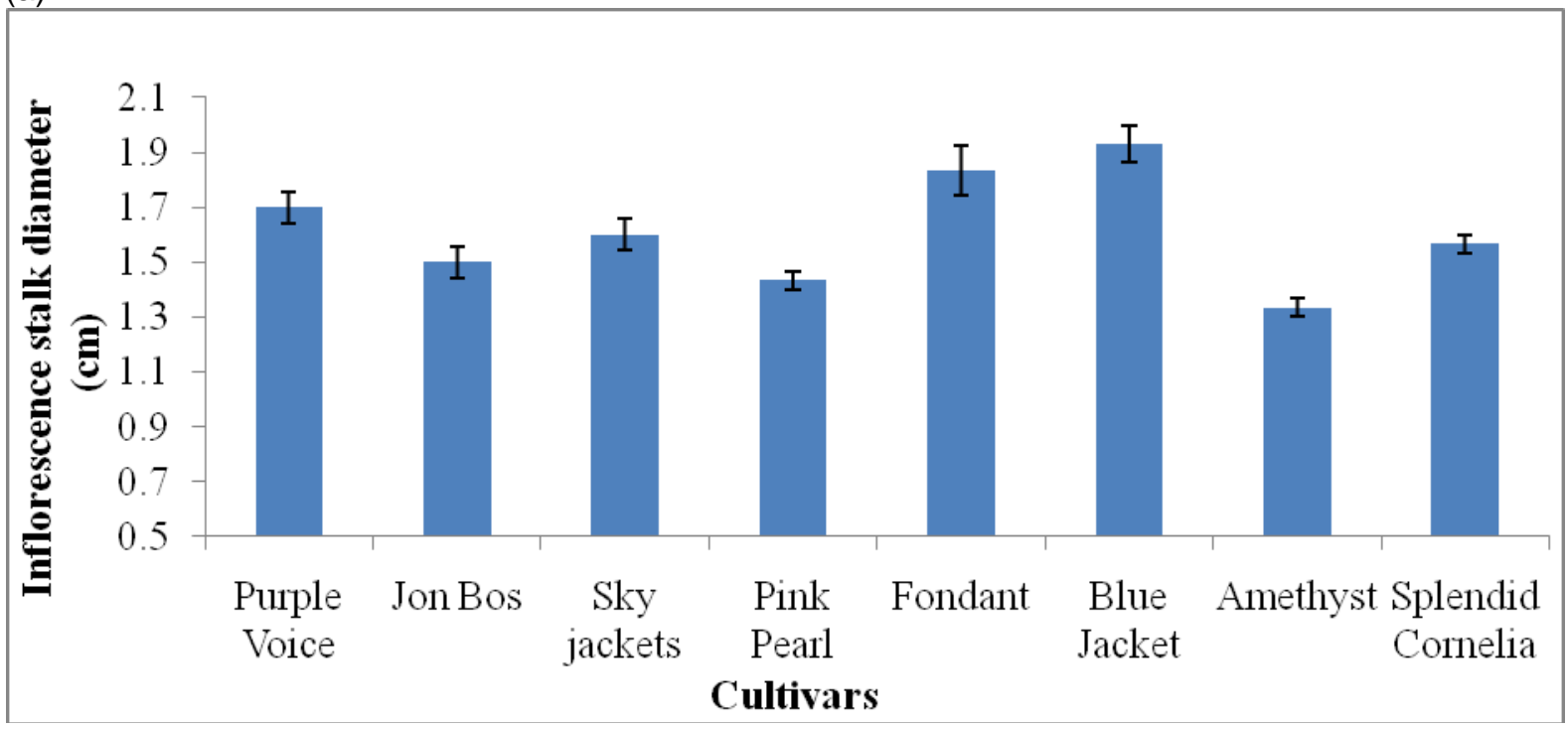

(b)

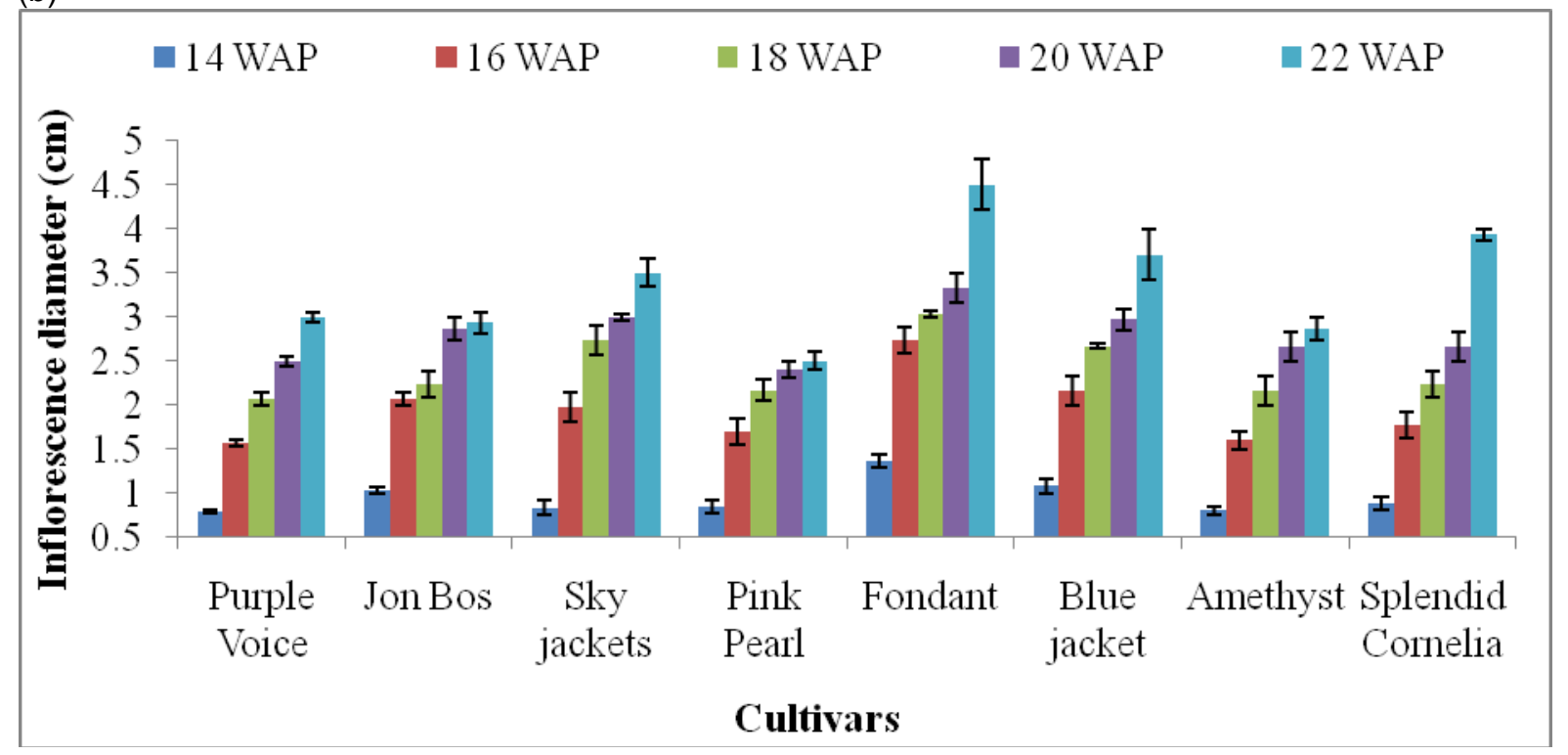

Fig 5: Influence of cultivar on (a) inflorescence stalk diameter, and (b) inflorescence diameter of hyacinth. Bars represent the mean values \pm standard error of five replicates. 
(a)

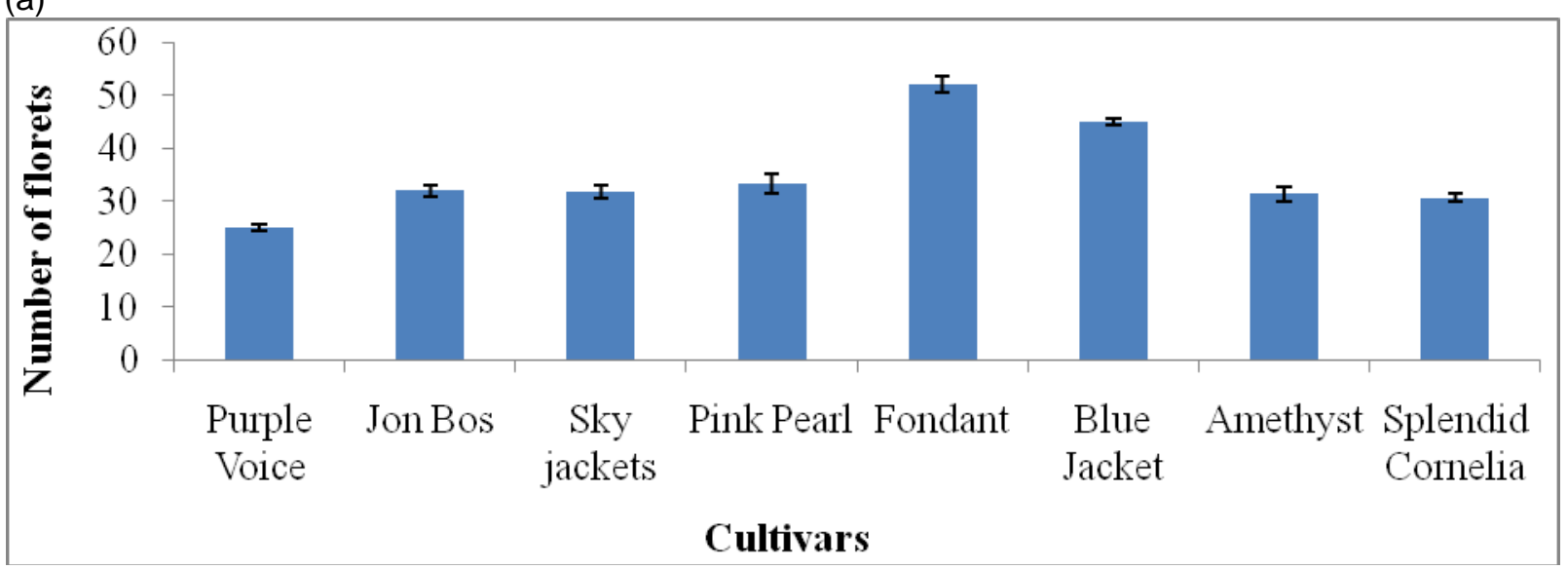

(b)

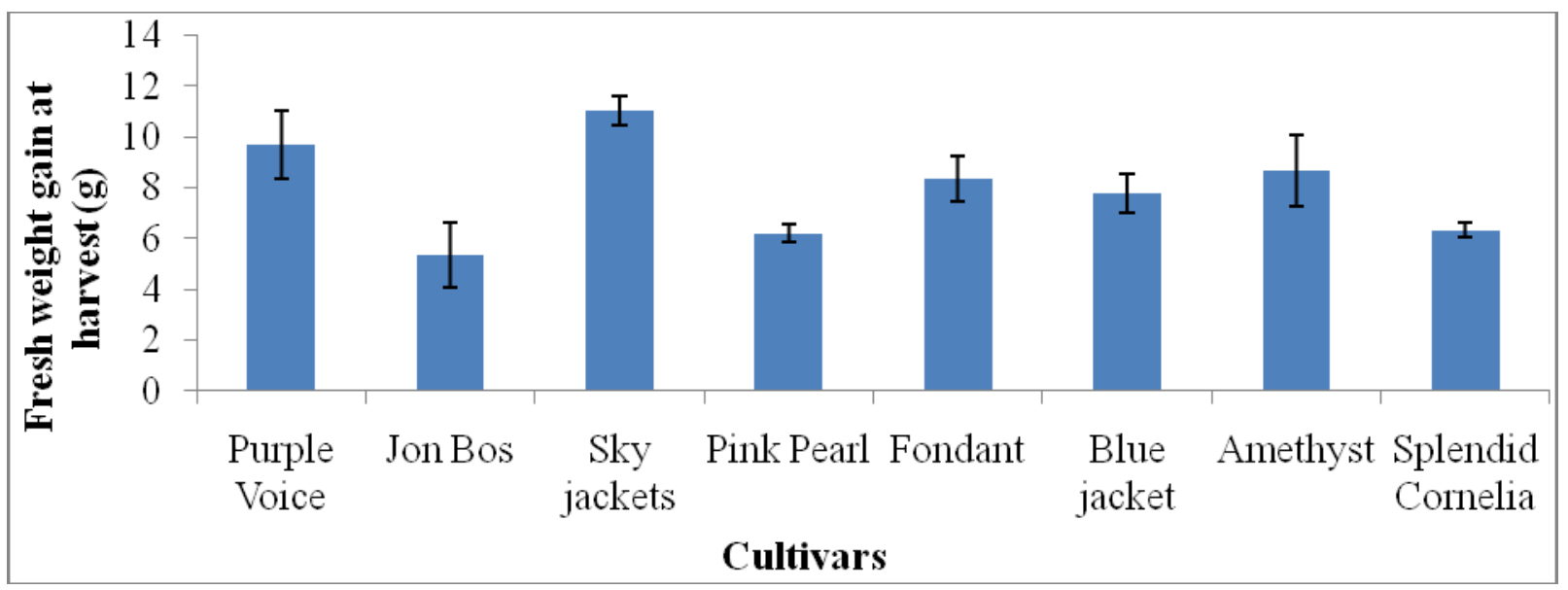

(c)

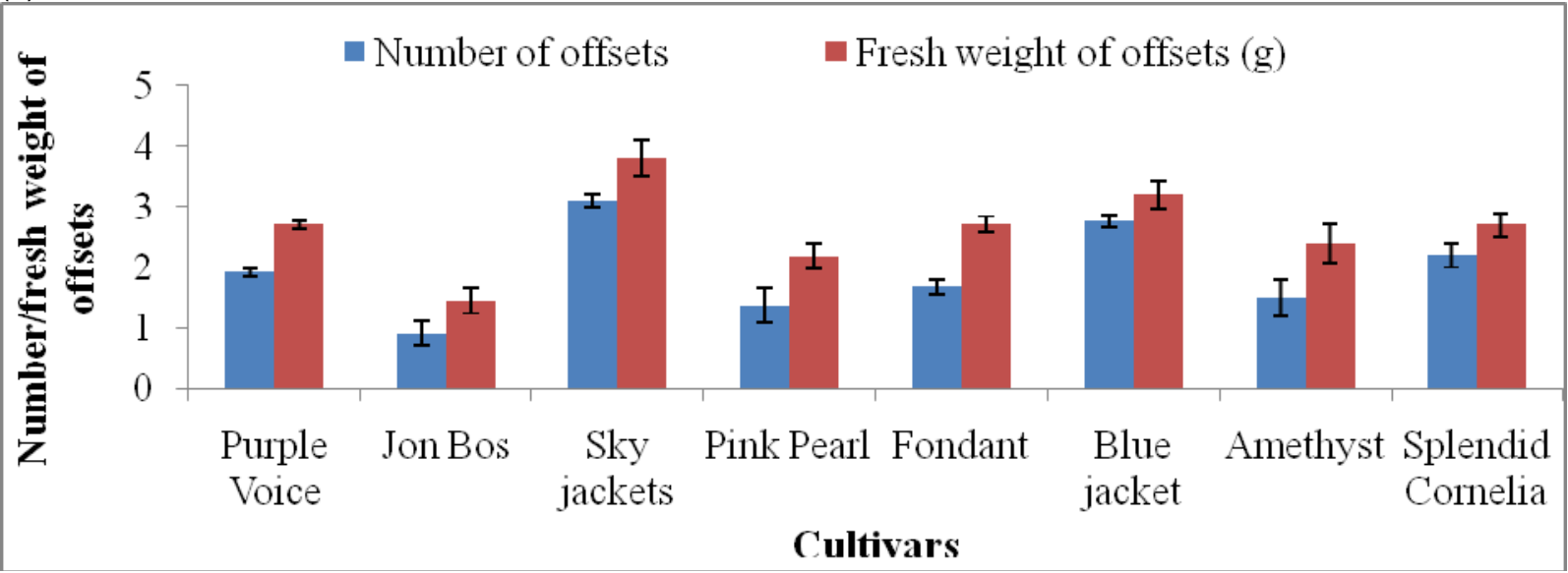

Fig 6: Influence of cultivar on (a) number of florets, (b) fresh weight gain of the mother bulb, and (c) offsets formation of hyacinth. Bars represent the mean values \pm standard error of five replicates. 
(a)

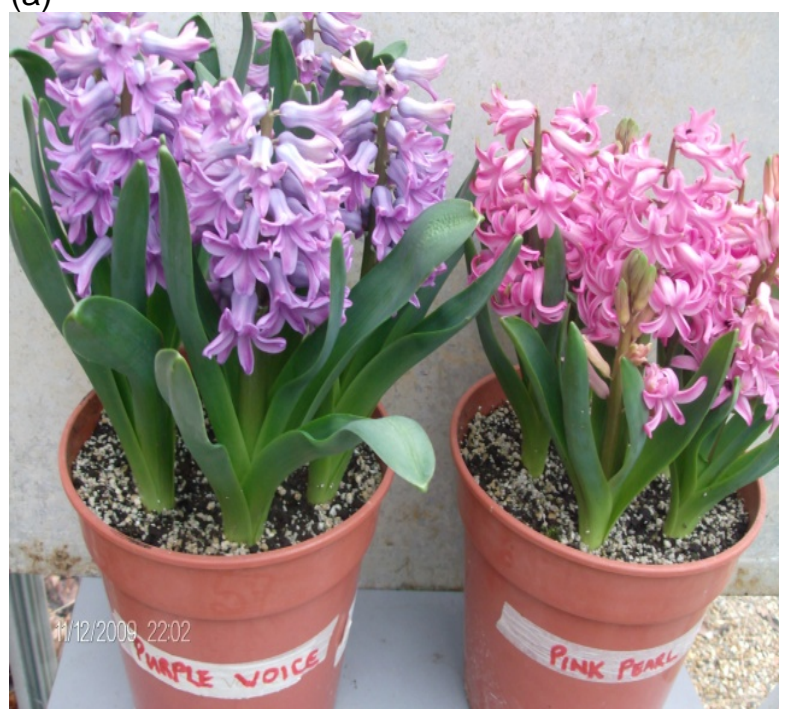

(c)

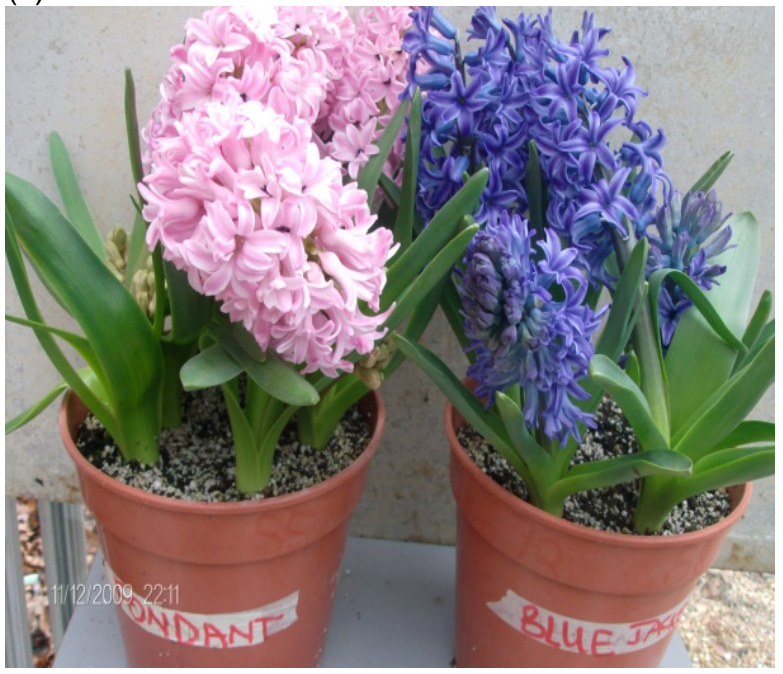

(b)

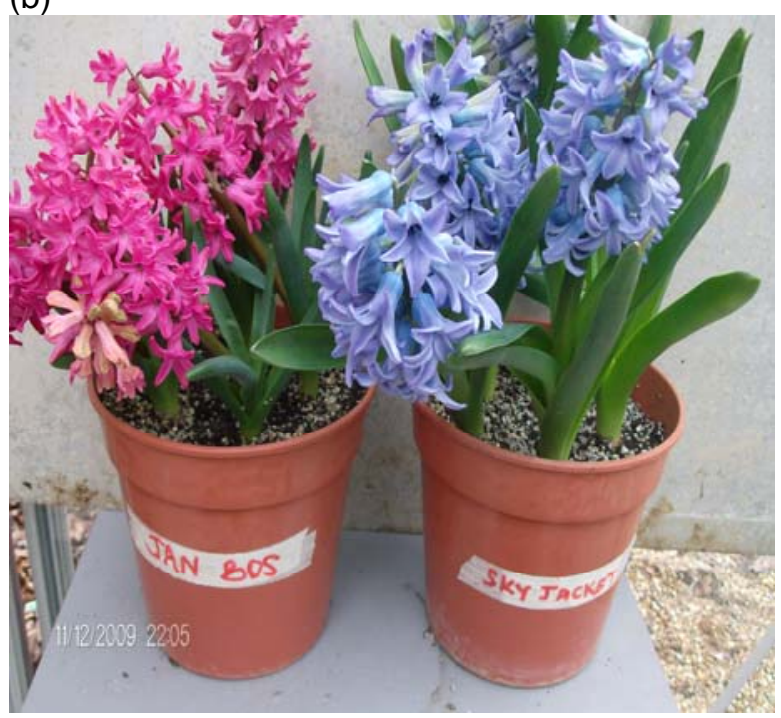

(d)

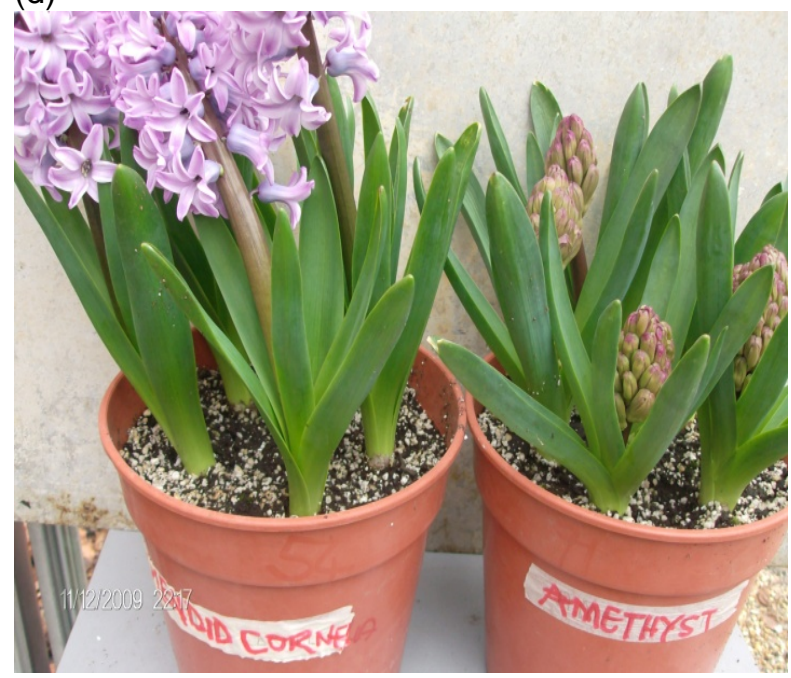

Fig 7: Evaluation of some cultivars of hyacinth; pictures were taken of these plants at 24 weeks after planting: (a) Purple voice (left) and Pink pearl (right), (b) Jon bos (left) and Sky jacket (right), (c) Fondant (left) and Blue jacket (right) and (d) Splendid cornelia (left) and Amethyst (right). 
(a)

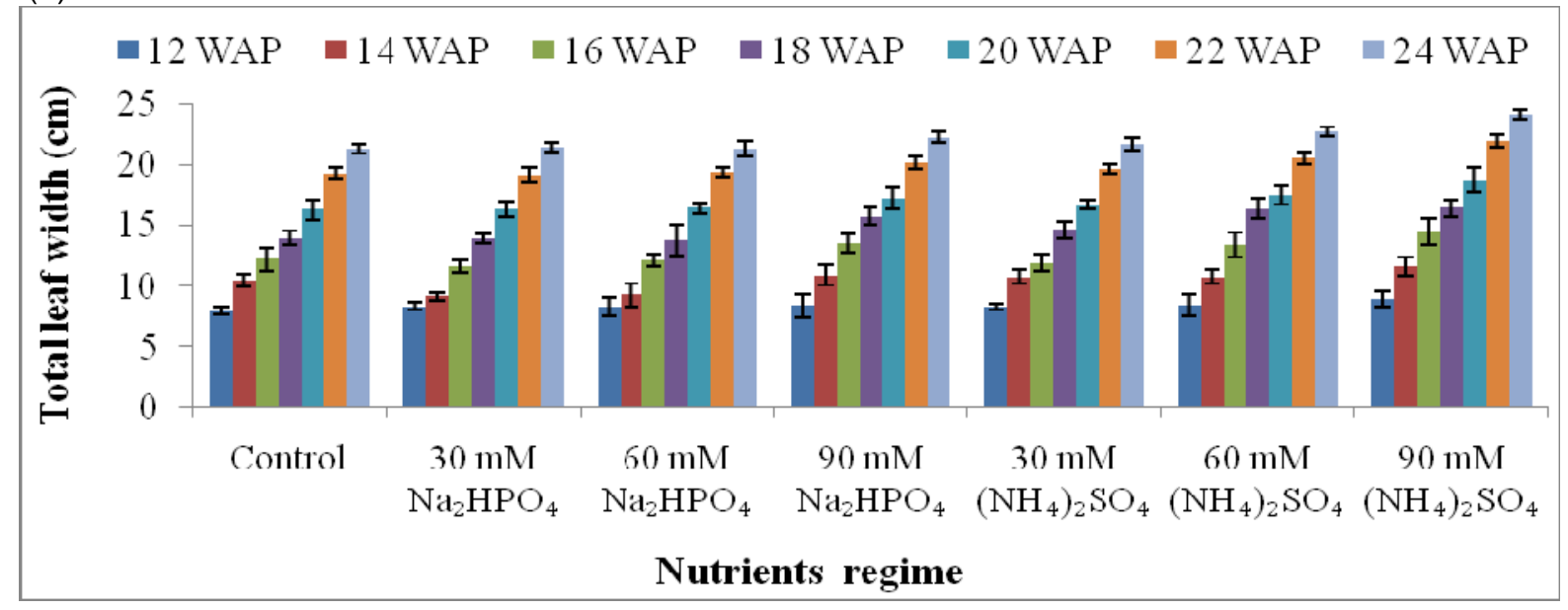

(b)

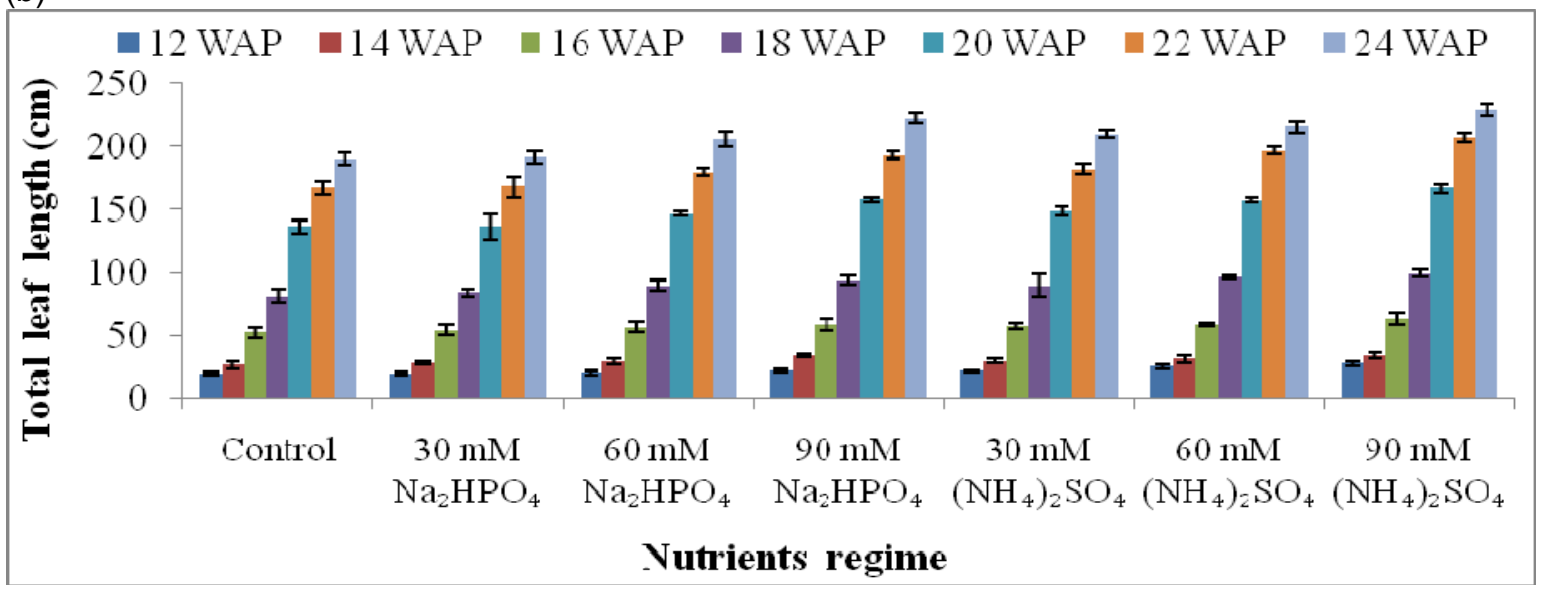

(c)

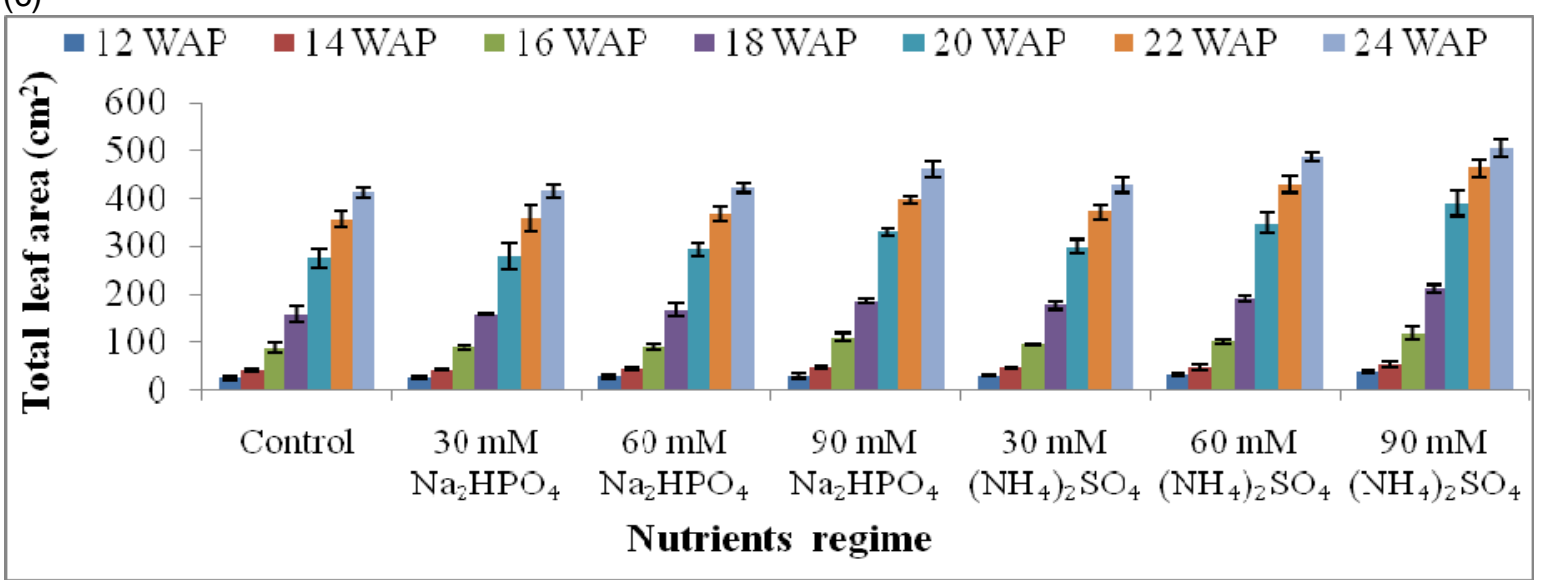

Fig 8: Influence of nutrients supply on leaf growth characteristics of hyacinth: (a) total leaf width, (b) total leaf length and (c) total leaf area. Results are mean values \pm standard error of five plants. 
(a)

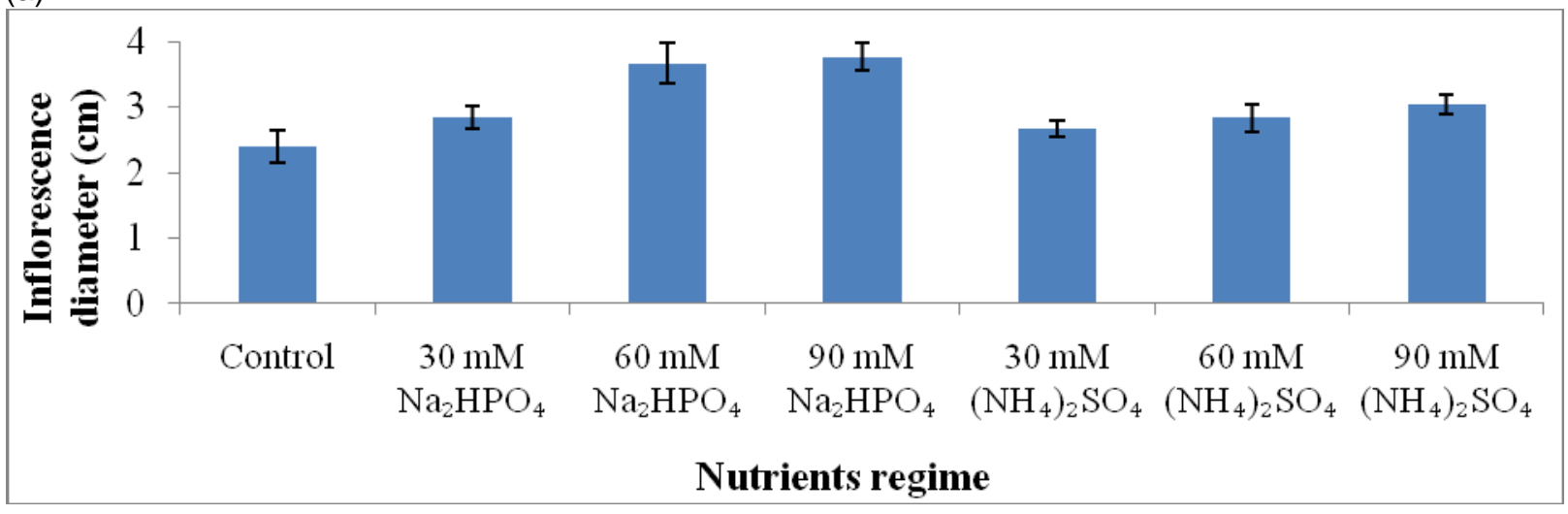

(b)

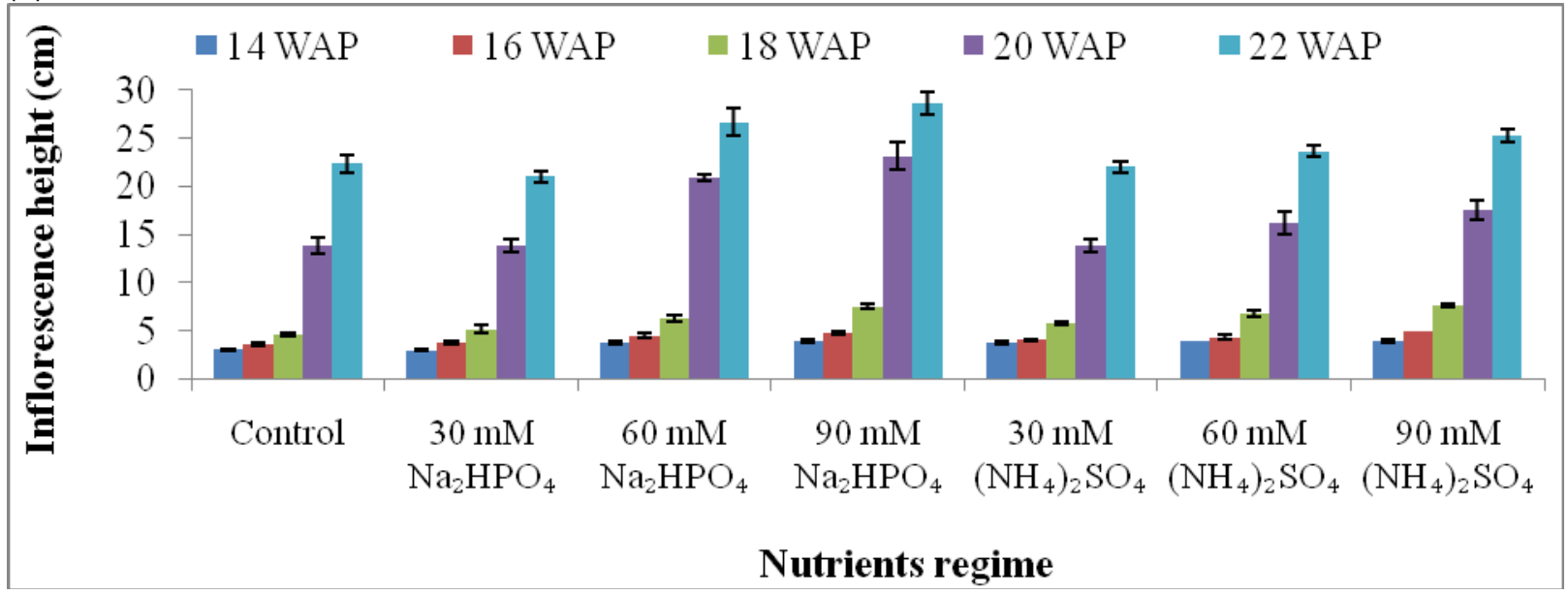

(c)

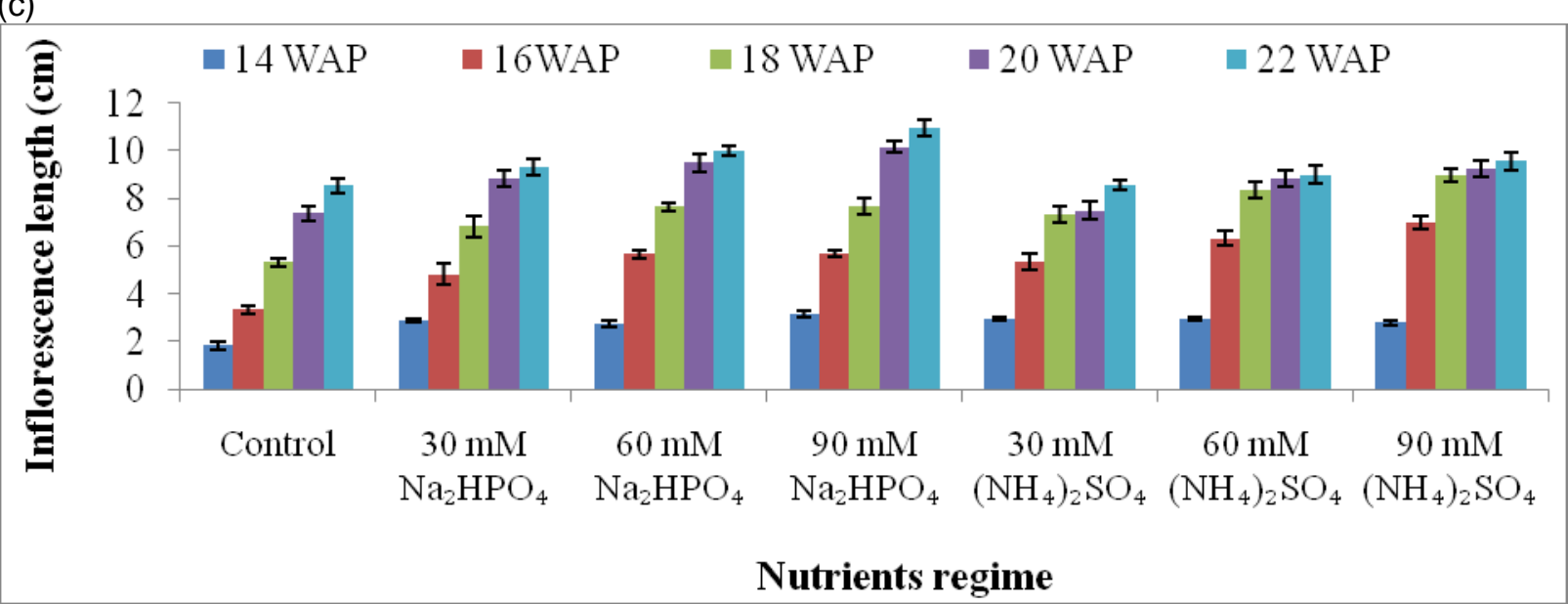

Fig 9: Effects of nutrients supply on inflorescence development of hyacinth, (a) inflorescence diameter, (b) inflorescence height and (c) inflorescence length. Results are mean values \pm standard error computed from five plants. 
(a)

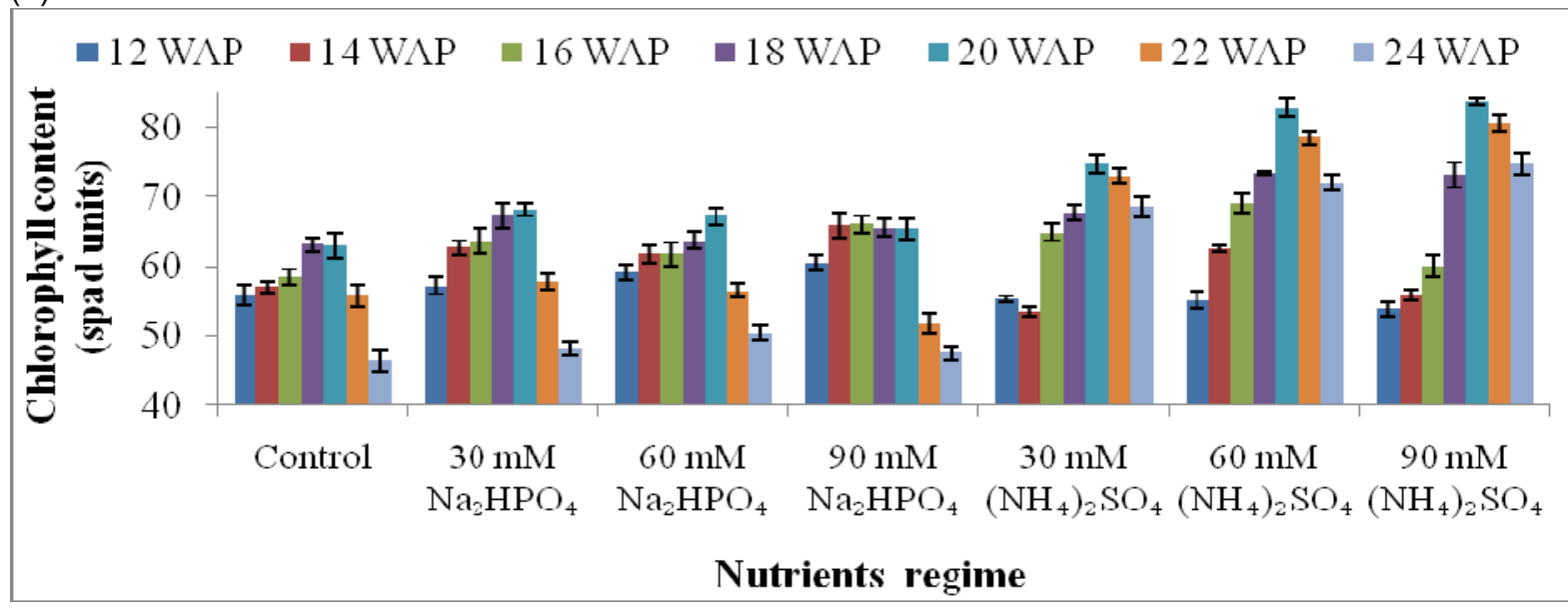

(b)

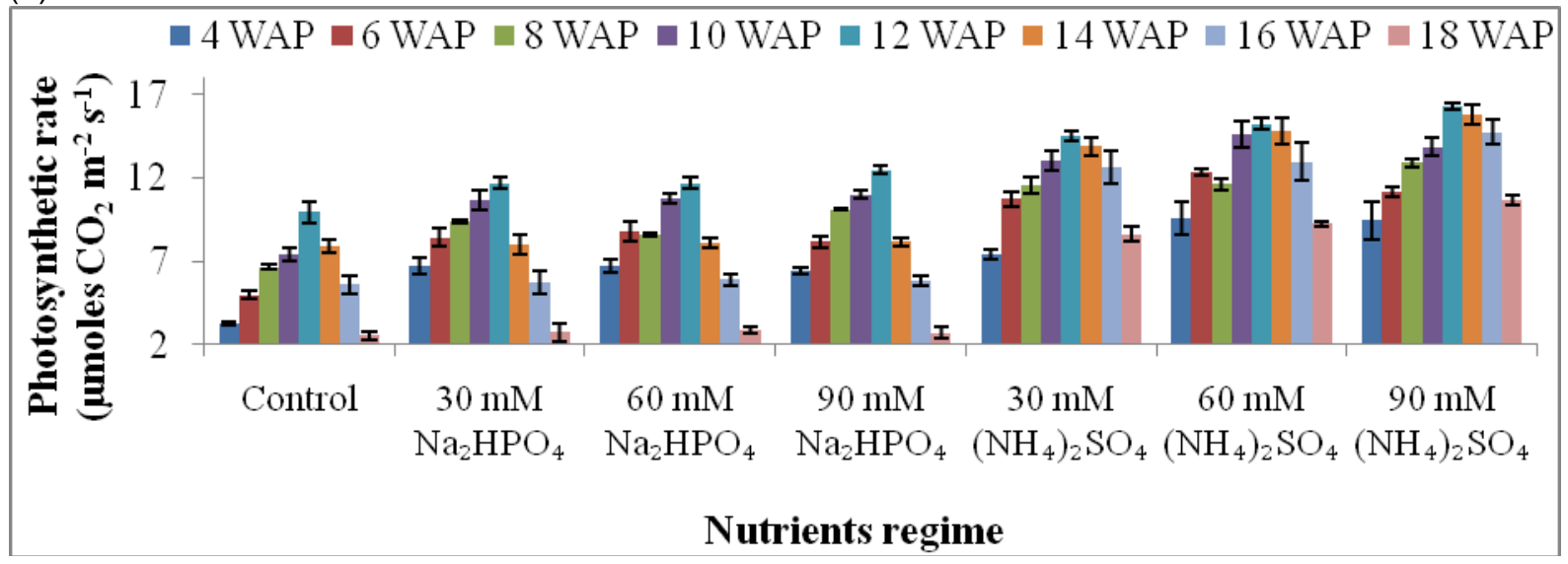

(c)

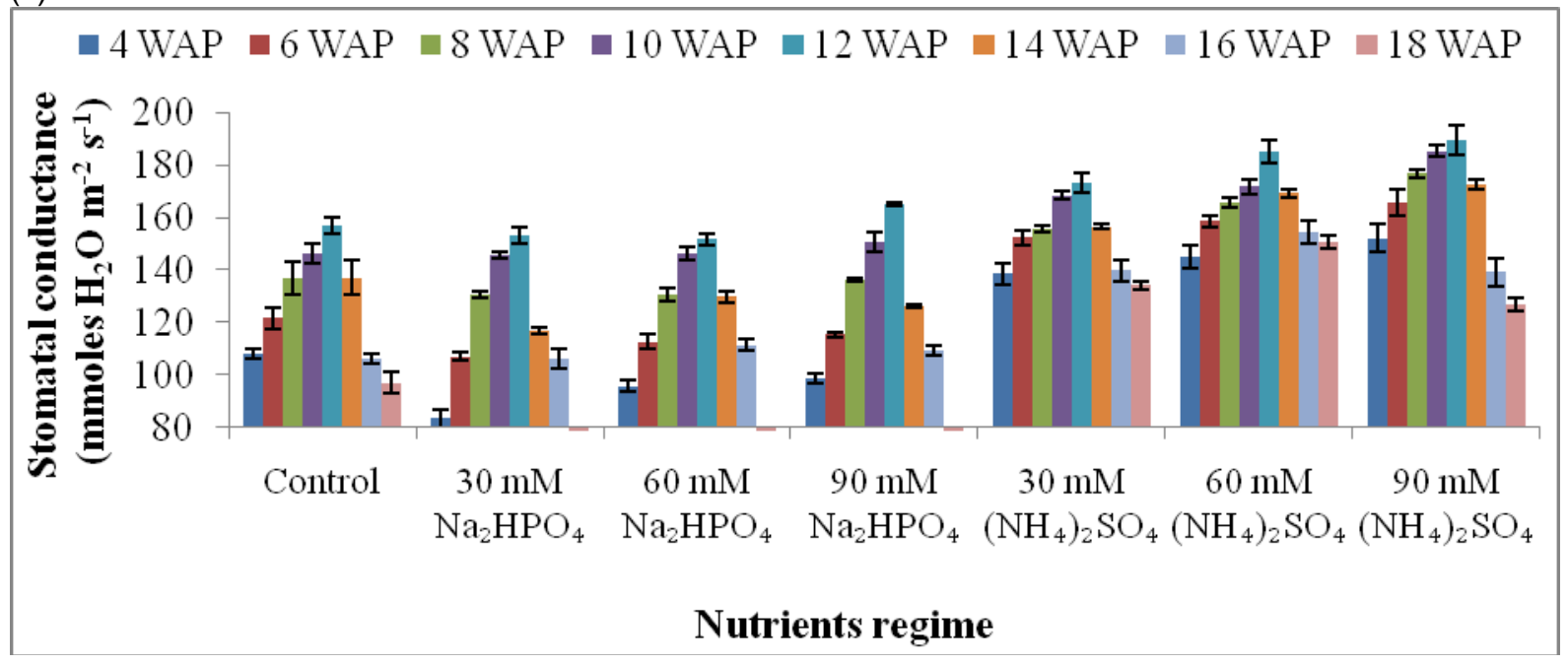

Fig 10: Impact of nutrients feeding on (a) chlorophyll content, (b) photosynthetic rate, and (c) stomatal conductance of the common hyacinth. Bars represent the mean values \pm standard error of three plants. Plants that received application of nutrients from $\left(\mathrm{NH}_{4}\right)_{2} \mathrm{SO}_{4}$ retained their chlorophyll longer than those fertilised with $\mathrm{Na}_{2} \mathrm{HPO}_{4}$ and the control. 
(a)

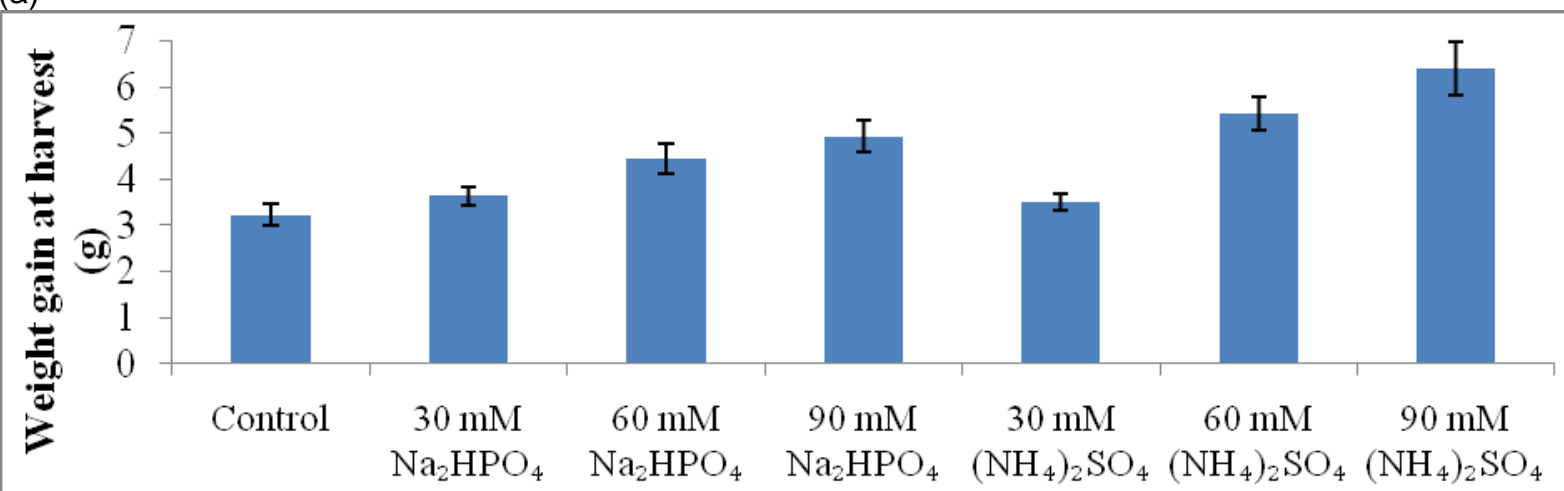

Nutrients regime

(b)

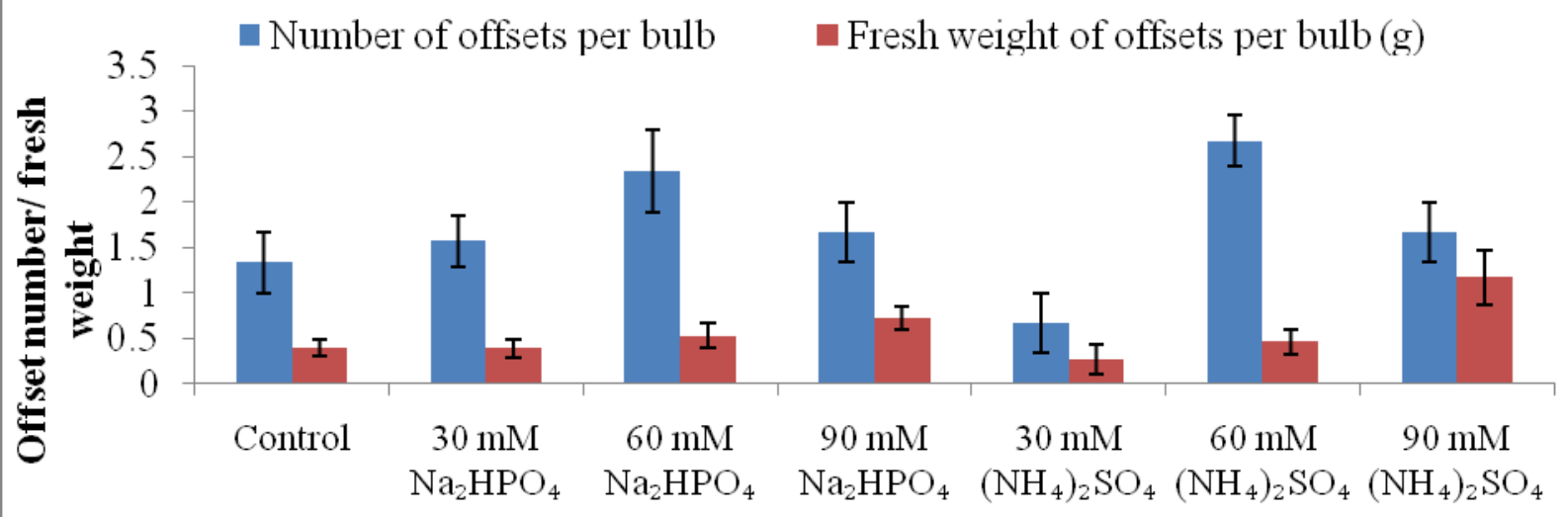

Nutrients regime

Fig 11: Influence of nutrients supply on: (a) weight gain at harvest and (b) bulblets formation of the hyacinth. The Bars refer to mean values \pm standard error of five replicates.

Bulbs and nutrients supply: The supply of the $\mathrm{N}$ and P-based nutrients increased leaf growth. Particularly, leaf length and area of hyacinth increased following the application of either 60 or 90 $\mathrm{mM} \mathrm{Na} \mathrm{HPO}_{4}$ or $\left(\mathrm{NH}_{4}\right)_{2} \mathrm{SO}_{4}$ as compared with the control. However, plants responded more positively to the application of $\left(\mathrm{NH}_{4}\right)_{2} \mathrm{SO}_{4}$ than they did with $\mathrm{Na}_{2} \mathrm{HPO}_{4}$ in terms of leaf growth because plants fed with the former recorded higher increases in leaf growth than those that received application from the latter (Fig 8). On the contrary, the application of $\mathrm{Na}_{2} \mathrm{HPO}_{4}$ at 60 or $90 \mathrm{mM}$ enhanced flower quality more than did $\left(\mathrm{NH}_{4}\right)_{2} \mathrm{SO}_{4}$ at the same rates of application. But in general, the two nutrients outperformed the control in terms of flower quality (Fig 9a, b and c). Plants fed with $\left(\mathrm{NH}_{4}\right)_{2} \mathrm{SO}_{4}$, even at the $30 \mathrm{mM}$ level, produced higher chlorophyll content than those that received nutrients from the $\mathrm{Na}_{2} \mathrm{HPO}_{4}$ (Fig 10a) and the control, and this also reflected in their photosynthetic rates and stomatal conductance (Fig $10 \mathrm{~b}$ and c). In general, chlorophyll content, photosynthetic rate and stomatal conductivity of plants increased as the level of applied $\left(\mathrm{NH}_{4}\right)_{2} \mathrm{SO}_{4}$ increased, and plants to which $\mathrm{Na}_{2} \mathrm{HPO}_{4}$ was applied produced values of these parameters that did not vary significantly from those of the control. The trend observed with gain in fresh weight at harvest (Fig 11a) as a result of the nutrients application mimicked the distribution pattern exhibited by leaf growth and chlorophyll formation, that is plants that received nutrients from $\left(\mathrm{NH}_{4}\right)_{2} \mathrm{SO}_{4}$ produced the highest gain in fresh weight of the mother bulb at harvest, and especially those fed with $90 \mathrm{mM}\left(\mathrm{NH}_{4}\right)_{2} \mathrm{SO}_{4}$ were very outstanding. There was no clear cut relationship between nutrients application and number of bulblets formed (Fig 11b), though the fresh weights of offsets formed seemed to be higher as the level of the applied nutrients increased. 


\section{DISCUSSION}

Cultivar effects: Though the pot in which the bulbs were grown were uniformly arranged on the greenhouse benches, variations in the distribution of light (intensity and duration), humidity, temperature or any other growth factor in the experimental site with respect to the locations of the plants, might have contributed to the observed differences in the growth of the plants. The differences in the cultivars due to their genetic constitution are also responsible for variations in characteristics of these cultivars. This agrees with the observation made by Ehsan et al. (2008), Treder (2000) and Troughton (1970) that variations in the characteristics of cultivars may be due to among other factors, differences in their genetic constitution. Mulder and Bijma (2005) also reported that genotype $\mathrm{x}$ environment interactions play a major role in influencing the growth and development of plants. Anwar et al. (2002) and Copur (2006) also observed some differences in characteristics of a number of cultivars of cotton. The high leaf growth of Sky Jacket implies that it had a higher photosynthetic apparatus and leaf canopy architecture than the other cultivars. This cultivar recorded the highest chlorophyll concentration. The high leaf biomass coupled with the high chlorophyll content of Sky Jacket might have enhanced its rate of photosynthesis and this reflected not only in the weight gain of the mother bulb of this cultivar but also the number and weight of bulblets at the time of harvest. Similarly, Jon Bos and Pink Pearl recorded the least gain in weight at harvest because they had low chlorophyll content and low photosynthetic apparatus that might have contributed to their relatively low values of photosynthetic rates. This is in accordance with the finding made by Stahlschmidt et al. (1994) in garlic. According to these authors, variety Rosado had low bulb dry weight at harvest because it recorded low leaf area ratio that resulted from the cultivar's smaller photosynthetic apparatus. The present study, however, showed that cultivars Fondant and Blue Jacket produced the highest flower biomass or quality because they had relatively high inflorescence height, inflorescence length and number of florets as compared with the other cultivars. However, these cultivars had lower leaf growth and fresh weight gain as compared to Sky Jacket. Thus the relatively low gain in bulb weight at harvest of Fondant and Blue Jacket may not only be attributable to their low photosynthetic leaf surface or chlorophyll concentration, but also probably due to the fact that assimilates from current photosynthesis and/or reserves stored in the bulb prior to planting were diverted for inflorescence development instead of leaf growth. In plant production, competition among organs for the reserves stored in the bulbs scales reduces the amount of these reserves that will be available for flower development (Caldwell et al., 1987). The inflorescences in cultivars Fondant and Blue Jacket might have had competitive advantage over the leaves in terms of acquisition of resources in terms of carbohydrate reserves for growth, and thus more of the reserves were channelled into the flowers for the development of the inflorescence instead of leaf growth. In fact, in flower bulbs, the inflorescence is an important sink organ (Die et al., 1970), and since inflorescence depends on the reserves stored in the bulb scales and/or current photosynthesis for their growth and development (Wassink, 1965), it follows that, if inflorescences have competitive advantage over the leaves in terms of acquisition of resources for growth, that is before photosynthesis sets in, as occurs when the leaves are too young to photosynthesize, then inflorescence will develop or grow at the expense of leaf growth. This scenario might have occurred during the growth and development of cultivars Fondant and Blue Jacket. The present study has revealed that it would be advisable for growers of hyacinth to consider Sky Jackets and Purple Voice in their selection of cultivars during the planting season for growth if their desired aim is to get high bulb yield at harvest, or if they consider bulblets production as their aim in the growth of this species. Otherwise, cultivars Fondant or Blue Jacket should be selected for planting because they have the good genetic potential for producing high flower quality for use particularly in the perfumery industry, because hyacinth flowers are also used in the manufacturing and processing of essential oils and perfumes (Gender, 1994; Usher, 1974). The greater the quantity of flowers produced, the higher the amount of oils and perfumes that will be extracted. Cultivar Fondant and Blue Jacket must be considered by growers who wish to produce these flowers for perfumery uses. The other cultivars of this flower bulb should be ideal for planting for their use as cut flowers, potted plants or as landscaping plants, but for indoor decorations, cultivars such as Pink Pearl and Jon Bos can be considered because they are small and portable, and can easily be handled as potted plants.

Nutrients feeding effects: Nutrients application in general increased vegetative growth of the plants, however, plants fed with $\left(\mathrm{NH}_{4}\right)_{2} \mathrm{SO}_{4}$ recorded higher 
vegetative growth, retained their florets for a longer time and had longer life cycle than the control and those fertilised with $\mathrm{Na}_{2} \mathrm{HPO}_{4}$. This observation is in support of Mahgoub et al. (2006) who worked on Irish bulb and reported that plant height, leaf biomass and inflorescence length increased when the bulb was fertilised with nitrogen at the rate of $40 \mathrm{~g}$ plus $30 \mathrm{~g}$ $\mathrm{K} / \mathrm{m}^{2}$. In the present study, there were increases in leaf growth, mother bulb fresh weight and bulblets yield at harvest as the level of applied $\left(\mathrm{NH}_{4}\right)_{2} \mathrm{SO}_{4}$ increased. In general, $\left(\mathrm{NH}_{4}\right)_{2} \mathrm{SO}_{4}$ is a nutrient source for nitrogen and nitrogen is known to play a major role during growth and development of plants (Scott 2008). In fact, nitrogen is a constituent of other plant compounds such as chlorophyll, cell wall and nucleotides (Havlin et al. (1999). In the soil, the element is absorbed as $\mathrm{NH}_{4}^{+}$ions (Bennett, 1993) and these ions are then transformed in the plants to the amine form, and utilised to form amino acids which are essential for protein formation (Bergmann, 1992). Nitrogen is an integral component of plant enzymes, and because enzymes play a major role in a number of metabolic processes in plants, it is not surprising that nitrogen played a key role in the growth and development of this geophyte. The observed increases in vegetative growth and bulb yield of plants fed with nitrogen, among other factors are due to the increase in chlorophyll values and delayed senescence of these plants, that also reflected in their high rates of photosynthesis as compared with the control and plants fed with $\mathrm{Na}_{2} \mathrm{HPO}_{4}$. It has already been established that (Addai, 2010) after planting, the level of reserved carbohydrates stored in flower bulbs decreased during and after sprouting. Thus replenishing the nutrients lost from the bulb during sprouting, through nutrients application is responsible for the relatively high growth and development of this flower bulb as compared to the control.

The research reported here has revealed that, whilst $\left(\mathrm{NH}_{4}\right)_{2} \mathrm{SO}_{4}$ at the rate of 60 and $90 \mathrm{mM}$ but particularly the latter rate, gave the best performance in terms of vegetative growth, bulb, as well as bulblets production in this geophytic plant, it was the supply of $\mathrm{Na}_{2} \mathrm{HPO}_{4}$ at the rate of 60 or $90 \mathrm{mM}$ that gave the best performance in terms of flower quality in hyacinth. Hamit (2001) also observed that the application of phosphorus increased the number of spikes, but the number of florets per plant in Freesia hybrida was not affected. In general, phosphorus is a nutrient element known to be a component of nucleic acids and genes. According to Bennett (1993), phosphorus plays a major role in the reproduction of plants because it enhances the production and maturation of flowers and fruits, and also improves their quality. Thus based on the results of this study, it would be recommended that the growth of hyacinth in pots should be accompanied by the application of $\left(\mathrm{NH}_{4}\right)_{2} \mathrm{SO}_{4}$ or any $\mathrm{N}$-based nutrients at the rate equivalent to $60-90 \mathrm{mM}\left(\mathrm{NH}_{4}\right)_{2} \mathrm{SO}_{4}$ to enhance plant growth and bulb yield. Similarly, $\mathrm{Na}_{2} \mathrm{HPO}_{4}$ or any $\mathrm{P}$ based nutrients should be applied at a rate equivalent to $60-90 \mathrm{mM} \mathrm{Na}_{2} \mathrm{HPO}_{4}$ to enhance flower quality.

\section{CONCLUSIONS AND RECOMMENDATIONS:}

The cultivars evaluated in this study differed in a number of characteristics. Sky Jacket recorded relatively high vegetative growth, chlorophyll content, photosynthetic rate, mother bulb as well as and bulblets yield at the time of harvest whilst Jon Bos and Pink Pearl recorded the least values of these parameters. Fondant and Blue Jacket produced the highest flower quality but they had low leaf growth and fresh weight gain at harvest. The study recommends Sky Jackets and Purple Voice to growers of this ornamental geophyte in their selection of cultivars or planting materials for propagation so that these growers can achieve high bulb yield or bulblets production. But for flower production or as cut flowers, Fondant or Blue Jacket should be used for planting because they have the genetic potential of producing high flower biomass or quality. These two cultivars may also be considered by growers who wish to produce the flower bulb for their perfumery uses. For indoor decorations, however, Pink Pearl or Jon Bos may be important because they are portable, and can easily be handled as potted plants. On nutrients application, the study showed that even though the application of the two nutrients increased vegetative growth of hyacinth, plants fertilised with $\left(\mathrm{NH}_{4}\right)_{2} \mathrm{SO}_{4}$ recorded higher vegetative growth, had longer life cycle and produced higher bulb and bulblets yield than the control and those fertilised with $\mathrm{Na}_{2} \mathrm{HPO}_{4}$. In general, $\left(\mathrm{NH}_{4}\right)_{2} \mathrm{SO}_{4}$ at the rate of 60-90 $\mathrm{mM}$ enhanced vegetative growth, bulb yield, as well as bulblets production in hyacinth, however, it was the supply of $\mathrm{Na}_{2} \mathrm{HPO}_{4}$ at the rate of $60-90 \mathrm{mM}$ that enhanced flower quality in hyacinth. Therefore, it would be recommended that the growth of this flower bulb in pots should be accompanied by the application of $\left(\mathrm{NH}_{4}\right)_{2} \mathrm{SO}_{4}$ or any $\mathrm{N}$-based nutrients at the rate equivalent to $60-90 \mathrm{mM}\left(\mathrm{NH}_{4}\right)_{2} \mathrm{SO}_{4}$ to enhance plant growth and bulb yield. Also, $\mathrm{Na}_{2} \mathrm{HPO}_{4}$ or any $\mathrm{P}$ - based nutrients should also be incorporated at a rate equivalent to $60-90 \mathrm{mM} \mathrm{Na} \mathrm{Na}_{2} \mathrm{HPO}_{4}$ to 
enhance flower quality. The study did not, however, investigate the combined effects of these nutrients on growth and yield of the bulb and thus it would be difficult at this stage to make any recommendations on the rates that would be suitable for optimum growth and yield of these bulbs when the two nutrients are applied at the same time. Future studies on effects of $\mathrm{N}$ and $\mathrm{P}$ in hyacinth or any other geophyte should have to determine these rates when they are both applied to the bulb. There would also be the need in the future to investigate the combined influence of cultivar and nutrients application on growth and development of hyacinth.

\section{REFERENCES}

Addai, I. K. (2010). Growth and biochemistry of the common hyacinth (Hyacinthus orientalis L.) and the lily (Lilium longiflorum L.). PhD Thesis, Biology, University of Sussex, July 2010, UK.

Anwar, A. M., Gill, M. I., Muhammad, D. and Afzal, M. N. (2002). Evaluation of cotton varieties at different doses of nitrogen fertilizer. The Pak. Cottons, 46(1-4): 35-41.

Bergmann, W. (1992). Nutritional disorders of plants: development, visual and analytical diagnosis. Gustav Fisher Verlag Jena, New York.

Bennett, W. F. (1993). Plant nutrient utilization and diagnostic plant symptoms. In W.F.Bennett (Ed). Nutrient deficiencies and toxicities in crop plants. APS Press, St Paul, Minnesota.

Caldwell, M. M., Richards, J. H., Manwaring, J. H. and Eissenstat, D. M. (1987). Rapid shift in phosphate acquisition show direct competition between neighbouring plants. Nature 327; 615-616

Copur, O. (2006). Determination of yield and yield components of some cotton cultivars in semi arid conditions. Pak. J Biol. Sci. 9(14) 2572-2578.

Ehsan, F., Ali, A., Ather Nadeem, M., Tahir, M. and Majeed, A. (2008). Comparative Yield Performance of New Cultivars of Cotton (Gossypium Hirsutum L.) Pak. J. Life Soc. Sci. 6(1): 1-3.

Hamit Altay, Canan Öztokat, Mürsel Güven. (2001). Effect on Yield and Quality of varying Applications of nitrogen and phosphorus to Greenhouse Cultivation of Freesia Hybrida Çanakkale Onsekiz Mart University.

Darkwa, A. A. (2008). Growth and biochemistry of European orchids. PhD Thesis, Biology, University of Sussex, UK.

Davies, H. V. (1990). Carbohydrate metabolism during sprouting. Am potato J, 67: 815-827.
Die, J. Van, Leeuwangh, P. and Hoekstra, S. M. R. (1970). Translocation of assimilates in Fritillaria imperilis L. I. The secretion of ${ }^{14} \mathrm{C}$ - Labelled sugars by the nectarines in relation to phyllotaxis. Acta bot. Neerl. 19, 16; 23.

Doyle J., Joy, H. and Glenn, Z. (1995). Field-Grown Bulb Crops: An economic assessment of the feasibility of providing multiple-peril crop insurance. A report by the Economic Research Service, USDA for the Federal Crop Insurance Corporation, April 28, 1995.

Engelbrecht, G. M. (2004). The effects of nitrogen, phosphorus and potassium fertilization on the growth, yield and quality of Lachenalia. PhD Thesis, Agricultural Sciences, University of the Free State, Bloemfontein.

Genders, R. (1994). Scented Flora of the World. Robert Hale. London. ISBN 0-7090-5440-8.

Hanks, G. R. (2002). Production of Narcissus bulbs. In: Narcissus and Daffodils, the Genus Narcissus (Ed Gordon R. Hanks), pp 59-117.

Havlin, J. L., Beaton, J. D., Tisdale, S. L., and Nelson, W. L. (1999). Soil fertility and fertilizers: an introduction to nutrient management, $6^{\text {th }}$ edition, Practice Hall, London.

Heins, R. D., Liu, B. and Runkle, E. S. (2000). Regulation of crop growth and development based on environmental factors. Acta Hort. (ISHS) 514:13-24.

Kim, H. H., Ohkawa, K. and Nitta, E. (1998). Effects of bulb weight on the growth and flowering of Leucocoryne coquimbensis F. Phill. Acta Hort. 454: 341-346.

Mahgoub, H. M., Rawia, A. Eid. and Abou Leila Bedour, H. (2006). Response of Iris Bulbs Grown in Sandy Soil to Nitrogen and Potassium Fertilization. J Appl Sci. Res. 2(11): 899-903, 2006.

Mulder, H. A. and Bijma, P. (2005). Effects of genotype $x$ environment interaction on genetic gain in breeding programs. J. Anim. Sci. 2005. 83:49-61.

Rees, A. R. (1972). The growth of Bulbs. Applied Aspects of the physiology of ornamental bulbous crop plants. Academic Press Inc. (London) Ltd.

Scott, P. (2008). Mineral nutrition of plants. In: Physiology and Behaviour of Plants. John Wiley and Sons, Ltd. Pages 75-87.

Silberbush, M., Ephrath, J. E., Alekperov, Ch. and BenAsher, J. 2003. Nitrogen and potassium fertilization 
interactions with carbon dioxide enrichment in Hippeastrum bulb growth. Scientia Hort 98: 85-90.

Stahlschmidt, O., Cavagnaro, J. B. and Borgo, R. (1994). Growth analysis of three Garlic (Allium sativum I.) cultivars with differences in yield. ISHS Acta Horticulturae 433: I International Symposium on Edible Alliaceae. May, 1994.

Theron, K. I. and Jacobs, G. (1996). Changes in carbohydrate composition of the different bulb components of Nerine bowdenii W. Watson (Amaryllidaceae). J Am Soc Hortic Sci 121: 343346.
Treder, J. (2000). Wplyw nawozenia na wzrost i kwitnienie lilii orientalnych oraz zawartosc skladnikow mineralnych. Zesz. Nauk. ISK 7, 375-380 (in Polish with English abstract).

Troughton, A. (1970). Intra-varietal variation of yield in two varieties of Lolium perenne L. Euphytica 19 : 382-389.

Usher. G. A. 1974. Medicinal uses of plants. Dictionary of Plants Used by Man. Constable ISBN 0094579202.

Wassink, E.C. (1965). Light intensity effects in growth and development of tulips in comparison with those in gladiolus. Meded. LandbHoogesch. Wageningen 65 (15), 1-21. 